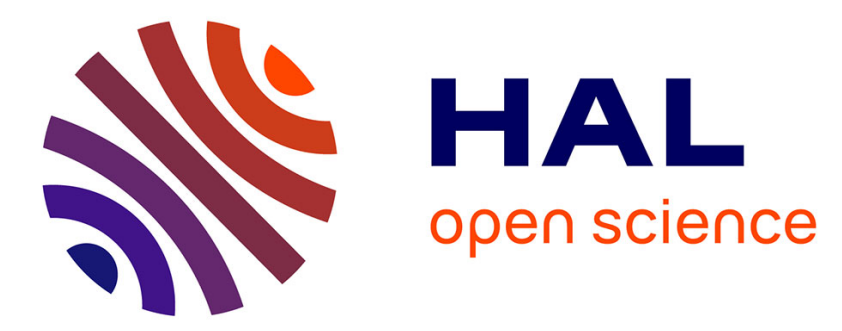

\title{
Application of the Curtius rearrangement to the synthesis of 1'-aminoferrocene-1-carboxylic acid derivatives
}

\author{
W. Erb, G. Levanen, T. Roisnel, V. Dorcet
}

\section{To cite this version:}

W. Erb, G. Levanen, T. Roisnel, V. Dorcet. Application of the Curtius rearrangement to the synthesis of 1'-aminoferrocene-1-carboxylic acid derivatives. New Journal of Chemistry, 2018, 42 (5), pp.38083818. 10.1039/c7nj05020h. hal-01740157

\section{HAL Id: hal-01740157}

\section{https://hal-univ-rennes1.archives-ouvertes.fr/hal-01740157}

Submitted on 26 Apr 2018

HAL is a multi-disciplinary open access archive for the deposit and dissemination of scientific research documents, whether they are published or not. The documents may come from teaching and research institutions in France or abroad, or from public or private research centers.
L'archive ouverte pluridisciplinaire HAL, est destinée au dépôt et à la diffusion de documents scientifiques de niveau recherche, publiés ou non, émanant des établissements d'enseignement et de recherche français ou étrangers, des laboratoires publics ou privés. 


\title{
Application of the Curtius rearrangement to the synthesis of 1'- aminoferrocene-1-carboxylic acid derivatives
}

\author{
William Erb, ${ }^{* a}$ Gael Levanen, ${ }^{a}$ Thierry Roisnel, ${ }^{a}$ and Vincent Dorcet ${ }^{\mathrm{a}}$ \\ The shortest synthesis of $N$-protected $1^{\prime}$-aminoferrocene-1-carboxylic acid from readily available ferrocene-1,1'-dicarboxylic \\ acid is reported. 1'-Azidocarbonylferrocene-1-carboxylic acid was first obtained by reaction of the latter with \\ diphenylphosphoryl azide. It was then converted into four amino acids by a Curtius rearrangement conducted in the \\ presence of tert-butanol, benzyl alcohol, 9-fluorenemethanol or allyl alcohol. The benzyl and allyl carbamate derivatives are \\ reported and characterized for the first time. The four corresponding new succinimidyl activated esters were also prepared \\ and their usefullness was demonstrated in peptide coupling. Various structures were elucidated by X-ray crystallography, \\ including 1'-azidocarbonylferrocene-1-carboxylic acid and 1,1'-diazidocarbonyl ferrocene.
}

\section{Introduction}

Since the pioneering study of Herrick and co-workers on the use of ferrocene-1,1'-dicarboxylic acid as a turn mimic in peptides, ${ }^{1}$ a lot of work has been done to understand, rationalize and use this organometallic scaffold in medicinal chemistry. ${ }^{2-4}$ Three types of peptides have been reported based on ferrocene-1,1'dicarboxylic acid (type I), ferrocene-1,1'-diamine (type II), and 1'-aminoferrocene-1-carboxylic acid (Fca, type III). Type I and II allow the formation of parallel peptides strands whereas type III leads to antiparallel orientation, typical of natural peptides.

Since then, the groups of Kraatz, Metzler-Nolte, Rapić and Heinze have been especially prolific in the study of this unnatural amino acid. Indeed, Fca has been incorporated in peptides of various lengths for conformation studies ${ }^{5-14}$ or for detection and sensing. ${ }^{15-18}$ It has also been used to access polyferrocenic structures to study electronic communication between the redox-active units ${ }^{19-26}$ and in various scaffolds for specific applications. ${ }^{27-36}$

Surprisingly, despite the wide use of Fca, the price of its commercially available $\mathrm{N}$-protected derivatives remains expensive, probably due to the lack of easy and fast syntheses. The first approach was reported by Butler and co-workers in 1998 starting from 1,1'-dibromoferrocene (Scheme 1, A). ${ }^{37} \mathrm{~A}$ first halogen/metal exchange using butyllithium, followed by trapping with $O$-benzylhydroxylamine affords $1^{\prime}$ bromoferrocene-1-amine. A second halogen/metal exchange followed by trapping with carbon dioxide leads to Fca. Being a zwiterrion, its purification proves highly difficult and esterification is necessary to get the pure product in an overall $44 \%$ yield. However, functional groups transformations remain to be done to obtain a product suitable for peptide coupling.
The same year, Okamura et al. proposed their own synthesis of Boc-protected Fca starting from ferrocenecarboxylic acid (Scheme 1, B). ${ }^{38} \mathrm{~N}$-Acetamidoferrocene is first made by a sequence of ester activation-azidation-Curtius rearrangement in the presence of acetic anhydride. A regioselective FriedelCrafts reaction followed by $t$ BuOK-mediated ketone cleavage leads to the free carboxylic acid. Acetamide deprotection and tert-butyl carbamate (Boc) protection finally afford protected Fca in an overall $10 \%$ yield. In 2002, Rapić and co-workers proposed an original approach based on a bis-ester desymmetrization (Scheme 1, C). ${ }^{39}$ Starting from 1,1'diacetylferrocene, bromine oxidation followed by esterification leads to the corresponding bis-ester. Selective hydrolysis then conducts to the monocarboxylic acid which is readily converted to the Boc-protected amino group by a sequence of acid activation-azidation-Curtius rearrangement. Ester saponification finally affords Boc-protected Fca. The use of benzyl alcohol in place of tert-butyl alcohol similarly provides benzyl carbamate (Cbz)-protected Fca. Therefore, from 1,1'diacetylferrocene, six steps are required to access Boc- and Cbzprotected $\mathrm{Fca}$ in $19 \%$ and $28.5 \%$ yield, respectively. Finally, in 2004, Heinze and co-workers reported an improvement of Okamura's synthesis (Scheme 1, D). ${ }^{40}$ The main differences lie in the synthesis of $\mathrm{N}$-acetamidoferrocene, here obtained from iodoferrocene by a $\mathrm{N}$-arylation-phthalimide deprotectionamidation sequence. Fluorenylmethyl carbamate (Fmoc)protected Fca is finally obtained following Okamura's sequence in a $32 \%$ overall yield. Although an improvement is here clearly noticed, all of these syntheses remain time consuming, due to successive introduction of each substituent or tedious protection-deprotection steps. 
(A)

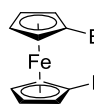

(B)

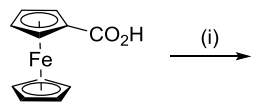

(C)

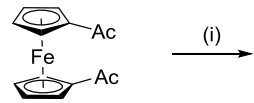

(D)

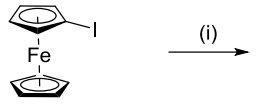

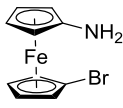
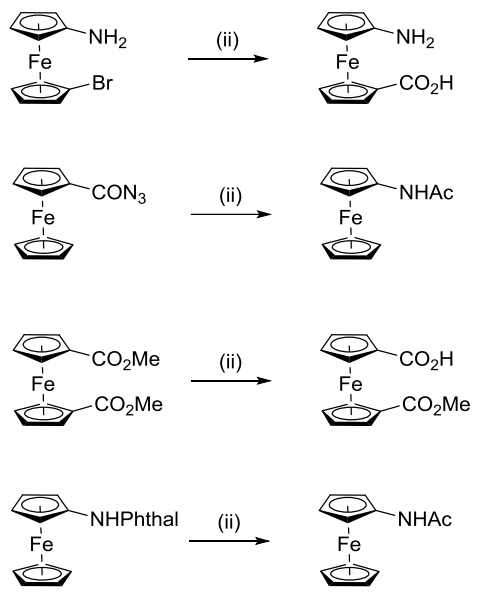
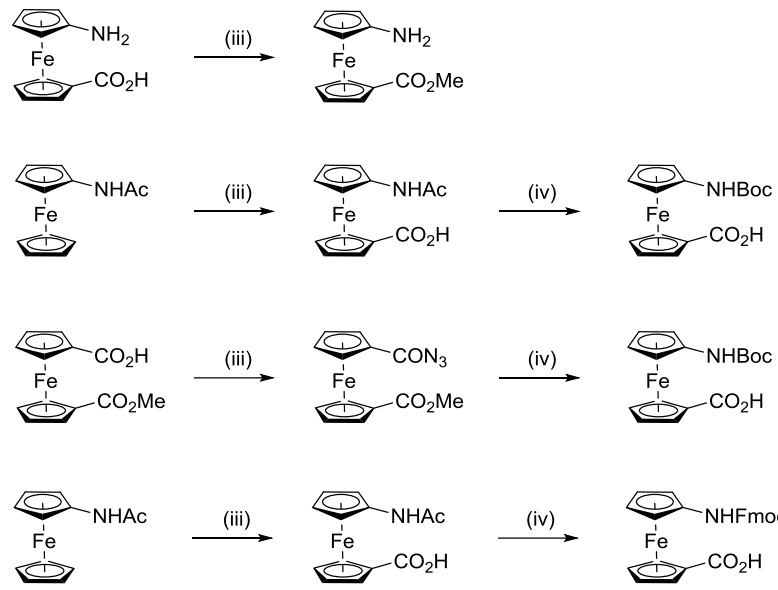
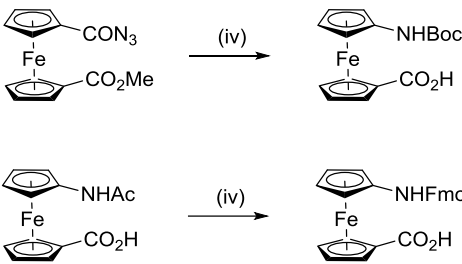
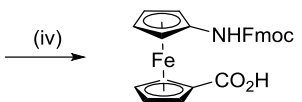

Scheme 1. Synthetic approaches toward 1'-aminoferrocene-1-carboxylic acid derivatives. (A) Synthesis proposed by Butler and co-workers: (i) (1) BuLi, (2) benzylhydroxylamine; (ii) (1) BuLi, (2) $\mathrm{CO}_{2}$; (iii) $\mathrm{HCl}$, MeOH. (B) Synthesis proposed by Okamura et al.: (i) (1) $\mathrm{ClCO}_{2} \mathrm{Et}$, (2) $\mathrm{NaN}_{3}$; (ii) (1) $\mathrm{Ac}_{2} \mathrm{O}$, (2) $\mathrm{H}_{2} \mathrm{O}$; (iii) (1) 2,6-Dichlorobenzoyl chloride, $\mathrm{AlCl}_{3}$, (2) $t \mathrm{BuOK}$; (iv) (1) $\mathrm{HCl}$, (2) $\mathrm{Boc}_{2} \mathrm{O}$, Phosphate buffer. (C) Synthesis proposed by Rapić and co-workers: (i) (1) $\mathrm{Br}_{2}, \mathrm{NaOH}$, (2) $\mathrm{MeOH}, \mathrm{H}_{2} \mathrm{SO}_{4}$; (ii) $\mathrm{NaOH}, \mathrm{MeOH}$; (iii) (1) $\mathrm{ClCO}_{2} \mathrm{Et}$, (2) $\mathrm{NaN}_{3}$; (iv) (1) $t \mathrm{BuOH}$, (2) $\mathrm{NaOH}$. (D) Synthesis proposed by Heinze and co-workers: (i) Copper phthalimide; (ii) (1) $\mathrm{N}_{2} \mathrm{H}_{4} \cdot \mathrm{H}_{2} \mathrm{O}$, (2) $\mathrm{Ac}_{2} \mathrm{O}$; (iii) (1) 2,6-Dichlorobenzoyl chloride, $\mathrm{AlCl}$, (2) $t \mathrm{BuOK}$; (iv) (1) $\mathrm{HCl}$, (2) 9-Fluorenylmethyl chloroformate, phosphate buffer.

In our eyes, the desymmetrization proposed by Butler and coworkers clearly appears as the shortest way to Fca. However, amination followed by carboxylation clearly complicates the isolation of pure material and we thought to reverse these steps, thus starting from ferrocene-1,1'-dicarboxylic acid.

Although dicarboxylic acids are classical substrates to access carbamate-protected amino acids, their desymmetrization are usually performed by bis-ester saponification, ${ }^{41-43}$ mono-ester formation ${ }^{44}$ or cyclic anhydride opening (either with an azide or $\mathrm{NH}_{3}$ ) reactions. ${ }^{45-47}$ All these approaches require multiple steps, and shorter routes have been less studied. They are based on Schmidt reaction or Curtius rearrangement. ${ }^{48,49}$ The use of toxic and explosive hydrazoic acid limited the application of the former. ${ }^{50}$ One the other hand, the Curtius rearrangement is a widely used reaction to convert carboxylic acid into an isocyanate through an acyl azide intermediate. Highly reactive, the isocyanate can then be trapped by nucleophiles to access amines, ${ }^{51-53}$ amides, $^{54-58}$ ureas, ${ }^{59-61}$ carbamates, ${ }^{62-65}$ thiocarbamates, $66-69$ and sulfonylureas. ${ }^{70-73}$ They can also be used in cycloaddition or electrocyclization. ${ }^{74-79}$ Introduced in 1972 by Yamada, the use of diphenylphosphoryl azide (DPPA) allows ester activation, azidation and Curtius rearrangement to be easily done in one-pot, facilitating the access towards isocyanates. ${ }^{80,81}$ However, its use for the desymmetrization of bis-carboxylic acid carbocycles has been scarcely reported. In 1996, Kahl and co-workers reported the transformation of carboranedicarboxylic acids into their corresponding amino acids under reaction with DPPA; different yields were obtained for each isomer: $83 \%(p), 80 \%(m)$ and $54 \%(o) .{ }^{82}$ Later, Berkesel reported low yields in the DPPA-mediated transformation of cyclohexane-1,2-dicarboxylic acid. ${ }^{45}$ In 2001 and 2003, pyridine2,6- and -3,5-dicarboxylic acids were engaged in such desymmetrizations by $\mathrm{Cho}^{83}$ and Nakayama ${ }^{84}$ with moderate yields, $45 \%$ and $46 \%$ respectively. Therefore, we can divide the substrates used in this approach into two classes depending on if (1) both carboxylic acids are close from each other or (2) carboxylic acids are spaced by a rigid linker. With a distance of $3.3 \AA$ between the two functional groups, ${ }^{85}$ ferrocene-1,1'dicarboxylic acid belongs to the first category (similar distances were noticed at the solid state for cyclohexane-1,2-dicarboxylic acid, $3.0 \AA$, and for 0 -carboranes, between 3.1 to $3.2 \AA$ ) ${ }^{86-88}$ Here, we report our efforts to control such challenging transformation toward the shortest synthesis of $\mathrm{N}$-protected Fca.

\section{Results and discussion}

We initially studied the Curtius rearrangement to access Bocprotected $\mathrm{Fca}(\mathbf{1})$ in a one-pot manner by the desymmetrization of ferrocene-1,1'-dicarboxylic acid (2). In a model reaction, 2 was suspended in toluene and treated with an excess of triethylamine and one equivalent of DPPA (Table 1). To favor the reaction of the intermediate isocyanate with tert-butanol rather than with the remaining carboxylate, we used a 20 -fold excess of alcohol. High dilution conditions $\left(0.04 \mathrm{~mol}^{\mathrm{L}} \mathrm{L}^{-1}\right)$ were also applied to limit intermolecular side-reactions. After $2 \mathrm{~h}$, we pleasingly observed the formation of the title product in an encouraging $20 \%$ yield. The use of $t \mathrm{BuOH}$ as solvent resulted in a major drop in the yield and we therefore kept toluene (entry 2). However, regardless of the reaction time (entries 1, 3 and 4), the order of addition of reagents (entry 5 ) or the excess of DPPA (entry 6), the yield invariably remained below $20 \%$. 
Table 1. Formation of $\mathbf{1}$ from ferrocene-1,1'-dicarboxylic acid (2).

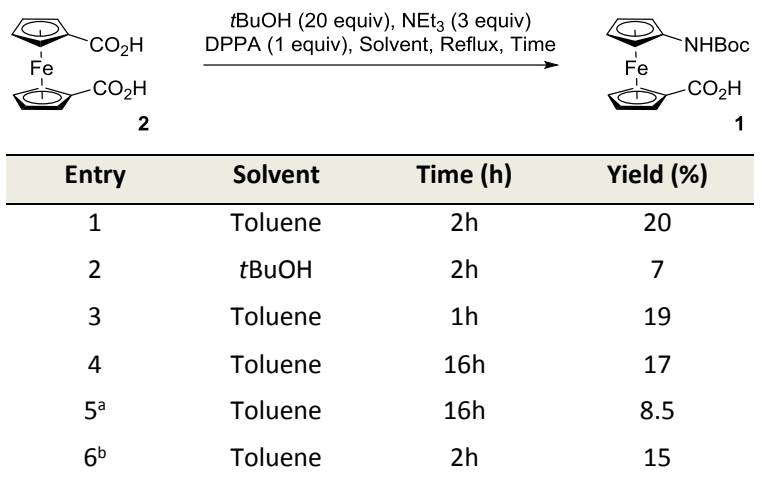

a $\mathbf{2}, \mathrm{NEt}_{3}$ and DPPA were mixed for $1 \mathrm{~h}$ at $\mathrm{rt}$ before addition of $t \mathrm{BuOH}$ and reflux. ${ }^{b} 1.2$ equiv of DPPA was used.

To identify the problematical step, we separately studied each stage of the process. We initially focused our attention onto the formation of the intermediate acyl azide. In a first reaction, ferrocene-1,1'-dicarboxylic acid (2) was mixed with a slight excess of triethylamine and one equivalent of DPPA in $\mathrm{CH}_{2} \mathrm{Cl}_{2}$ at room temperature. The reaction took $24 \mathrm{~h}$ to reach completion and afforded, after column chromatography, $31.5 \%$ of $1,1^{\prime}$ diazidocarbonylferrocene (3) and $29.5 \%$ of 1'azidocarbonylferrocene-1-carboxylic acid (4) (Table 2, entry 1). As the solubility of $\mathbf{2}$ in $\mathrm{CH}_{2} \mathrm{Cl}_{2}$ is rather limited, we next used an excess of base to favor the formation of a bis-ammonium salt. Not only the solubility increased, but the reaction time was shortened to $4 \mathrm{~h}$ (reaction monitored by IR, $\mathrm{N}_{3}$ stretching band, DPPA: $2170 \mathrm{~cm}^{-1} ; 3$ and $4: 2138 \mathrm{~cm}^{-1}$, see SI) and the ratio of bisto mono-azide changed (entry 2). Keeping a 4-fold excess of base, the reaction mixture was concentrated up to $0.52 \mathrm{~mol} . \mathrm{L}^{-1}$, resulting in shorter reaction times and in higher yields of 4 (entries 2-5). Finally, increasing the temperature from rt to 40 ${ }^{\circ} \mathrm{C}$ resulted in a very fast reaction (entry 6). Pleasingly, gramscale reaction could be conducted in a still correct yield of 4 (entry 7).

Table 2. Formation of $\mathbf{3}$ and $\mathbf{4}$ from ferrocene-1,1'-dicarboxylic acid (2).

\begin{tabular}{|c|c|c|c|c|c|}
\hline D & $\begin{array}{r}\mathrm{CO}_{2} \mathrm{H} \\
\mathrm{CO}_{2} \mathrm{H} \\
2\end{array}$ & $\begin{array}{l}\mathrm{Et}_{3}, \text { DPPA (1 equiv) } \\
\mathrm{CH}_{2} \mathrm{Cl}_{2} \text {, rt, Time }\end{array}$ & (1) & + & $\begin{array}{r}-\mathrm{CON}_{3} \\
-\mathrm{CO}_{2} \mathrm{H} \\
4\end{array}$ \\
\hline Entry & $\begin{array}{c}\mathrm{NEt}_{3} \\
\text { (equiv) }\end{array}$ & $\begin{array}{c}\text { Concentration } \\
\left(\mathrm{mol}^{\mathrm{L}} \mathrm{L}^{-1}\right)\end{array}$ & Time & 3 (\%) & $4(\%)$ \\
\hline $1^{a}$ & 1.2 & 0.065 & $24 \mathrm{~h}$ & 31.5 & 29.5 \\
\hline $2^{a}$ & 4 & 0.065 & $4 \mathrm{~h}$ & 22 & 28 \\
\hline $3^{a}$ & 4 & 0.13 & $3 \mathrm{~h}$ & 24 & 38.5 \\
\hline $4^{a}$ & 4 & 0.26 & $1 \mathrm{~h}$ & 22 & 44.5 \\
\hline $5^{a}$ & 4 & 0.52 & $30 \mathrm{~min}$ & 25 & 46.5 \\
\hline $6^{a, b}$ & 4 & 0.52 & $10 \mathrm{~min}$ & 23.5 & 58 \\
\hline $7^{b, c}$ & 4 & 0.52 & $10 \mathrm{~min}$ & 24.5 & 45.5 \\
\hline
\end{tabular}

${ }^{a}$ Reaction performed on $1.3 \mathrm{mmol}$ of $2 .{ }^{b}$ Reaction performed at $40{ }^{\circ} \mathrm{C}$. ${ }^{c}$ Reaction performed on $8 \mathrm{mmol}$ of 2 .
Even if an excess of base seems to promote the formation of the monoacyl azide 4, we were concerned by the double deprotonation of ferrocene-1,1'-dicarboxylic acid (2) which could led to 3. Therefore, we mixed $\mathbf{2}$ with a 4 -fold excess of base and, after evaporation of the solvent, a ${ }^{1} \mathrm{H}$ NMR study showed that double deprotonation occurred only to a moderate extent (1:0.3 mono/bisammonium ratio estimated). Furthermore, we managed to obtain crystals suitable for X-ray crystallography by slow evaporation of the solvent from the crude reaction mixture. The solid-state structure was consistent with the NMR results evidencing the main presence of the mono-ammonium 5 (Figure 1).

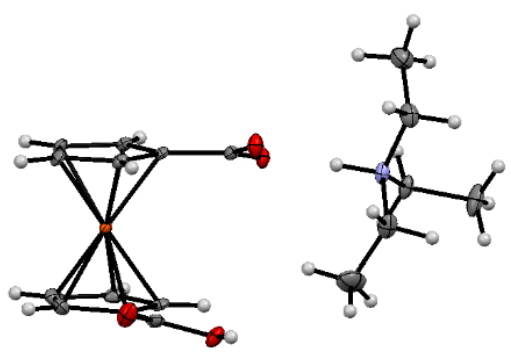

Figure 1. Molecular structure of compound 5 (thermal ellipsoids shown at the $30 \%$ probability level).

During this study, we also elucidated the solid-state structure of $\mathbf{3}$ and 4 by X-ray crystallography (Figures 2 and 3). In both cases, the cyclopentadienyl rings $(\mathrm{Cp})$ are in an eclipsed conformation (3: $\mathrm{C}^{15}$ $\mathrm{Cg}^{1} \ldots \mathrm{Cg}^{2}-\mathrm{C}^{3}$ pseudo torsion angle $1.0^{\circ}-\mathrm{Cg}$ denotes the centroids of the respective $\mathrm{Cp}$ ring; $4: \mathrm{C}^{15}-\mathrm{Cg}^{1 \ldots} \mathrm{Cg}^{2}-\mathrm{C}^{2}$ pseudo torsion angle $\left.0.6^{\circ}\right)$, and coplanar, as indicated by the $\mathrm{Cp}-\mathrm{Cp}$ planes angles (3: $1.4^{\circ} ; \mathbf{4}$ : $\left.1.1^{\circ}\right)$. In 3 , the $\mathrm{Cp}$ substituents are slightly less tilted when compared to 4 (3: $C^{1}-C^{5}-C^{6}-O^{7} 5.5^{\circ}, C^{14}-C^{15}-C^{16}-O^{17} 3.4^{\circ} ; 4: C^{1}-C^{5}-C^{6}-O^{8} 7.2^{\circ}, C^{11}$ $\left.\mathrm{C}^{15}-\mathrm{C}^{16}-\mathrm{O}^{17} 11.5^{\circ}\right)$.

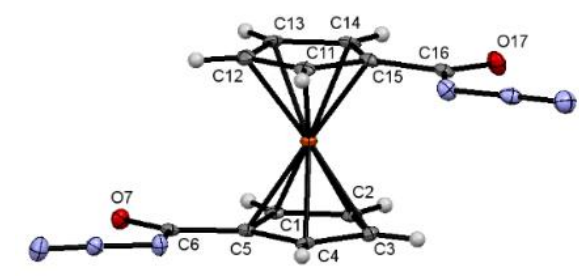

Figure 2. Molecular structure of compound $\mathbf{3}$ (thermal ellipsoids shown at the $30 \%$ probability level).

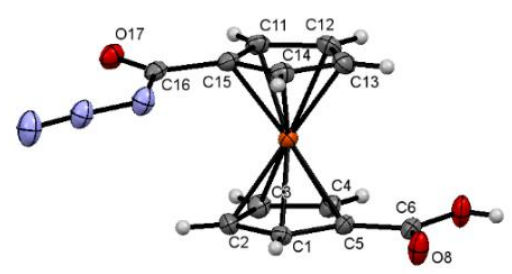

Figure 3. Molecular structure of compound $\mathbf{4}$ (thermal ellipsoids shown at the $30 \%$ probability level).

We then studied the thermal Curtius rearrangement of 4 in toluene at $110{ }^{\circ} \mathrm{C}$. In the absence of $t \mathrm{BuOH}$, we noticed the fast disappearance of the $\mathrm{N}_{3}$ stretching band. However, the isocyanate band $\left(2270 \mathrm{~cm}^{-1}\right)$ remained small during the reaction, to virtually 
disappear after $1 \mathrm{~h}$ heating (see $\mathrm{SI}$ ). The formation of a black precipitate as the reaction proceeds was also noticed, thus questioning the stability of the intermediate isocyanate. Indeed, addition of $t \mathrm{BuOH}$ after $1 \mathrm{~h}$ of heating only resulted in traces of amino acid.

Therefore, as the isocyanate derivative appears unstable on heating, we next conducted the Curtius rearrangement in the presence of $t \mathrm{BuOH}$. Using a 20 -fold excess of alcohol in diluted conditions $\left(0.02 \mathrm{~mol}^{\mathrm{L}} \mathrm{L}^{-1}\right)$, we managed to isolate $37.5 \%$ of $\mathbf{1}$ (Table 3 , entry 1 ), the rest of the mass balance being represented by baseline spots. We next raised the concentration up to $0.16 \mathrm{~mol}^{-\mathrm{L}^{-1}}$ and pleasingly observed better yields (up to $58 \%$, entries 1-4). However, if $t \mathrm{BuOH}$ is pretty cheap, the price of other alcohols, such as 9fluorenemethanol, is more concerning when such an excess has to be used. The impact of the amount of $t \mathrm{BuOH}$ was next studied and we found that the reaction works equally with only 2.5 equivalents (entries 4-7). However, even if the use of Brønsted and Lewis acids to accelerate the reaction has already been reported, ${ }^{89-91}$ Boc group deprotection was also observed, resulting in the formation of unprotected Fca (entries 8 and 9). The use of lower temperature did not allow us to isolate any protected amino acid in these conditions. However, gram-scale reaction is also possible with an almost similar outcome (entry 10).

Table 3. Formation of $\mathbf{1}$ from 4.

\begin{tabular}{|c|c|c|c|}
\hline Entry & Concentration (mol. $\mathrm{L}^{-1}$ ) & tBuOH (equiv) & $1(\%)$ \\
\hline $1^{a}$ & 0.02 & 20 & 37.5 \\
\hline $2^{a}$ & 0.04 & 20 & 42 \\
\hline $3^{a}$ & 0.08 & 20 & 54 \\
\hline $4^{\mathrm{a}}$ & 0.16 & 20 & 58 \\
\hline $5^{\mathrm{a}}$ & 0.16 & 10 & 52.5 \\
\hline $6^{\mathrm{a}}$ & 0.16 & 5 & 56 \\
\hline $7^{\mathrm{a}}$ & 0.16 & 2.5 & 70 \\
\hline $8^{b}$ & 0.16 & 2.5 & Traces $^{c}$ \\
\hline $9^{d}$ & 0.16 & 2.5 & Traces $^{\mathrm{c}}$ \\
\hline $10^{\mathrm{e}}$ & 0.16 & 2.5 & 59 \\
\hline
\end{tabular}

${ }^{a}$ Reaction performed on $0.4 \mathrm{mmol}$ of 4 . $^{b}$ Reaction performed in $\mathrm{AcOH} .{ }^{c}$ Unprotected Fca observed in crude reaction mixture by NMR. d Reaction performed in dioxane with 1 equiv of $\mathrm{BF}_{3} . \mathrm{OEt}_{2}$. ${ }^{\text {e Reaction }}$ performed on $5 \mathrm{mmol}$ of 4 .

Having identified the best conditions for each step, we combined them toward a one-flask, two-step protocol toward $N$-Boc protected Fca. We mixed ferrocene-1,1'-dicarboxylic acid (2) with an excess of $\mathrm{NEt}_{3}$ and one equivalent of DPPA in $\mathrm{CH}_{2} \mathrm{Cl}_{2}$ at $40{ }^{\circ} \mathrm{C}$. After $10 \mathrm{~min}$, volatiles were removed under vacuum. Toluene and $t \mathrm{BuOH}$ were added and the reaction mixture was heated at $110{ }^{\circ} \mathrm{C}$ for one hour. However, a disappointing $23 \%$ yield was noticed (Table 4 , entry 1 ). As the concentration step might favor unwanted intermolecular side reactions, we moved to dioxane to avoid a solvent switch, but this resulted in a yield drop (entry 2). Concerned with the excess of base, we next filtered the crude reaction mixture after acyl azide formation over acid resin, but no improvement was noticed (entry 3 ).
Table 4. Direct formation of 1 from 2.

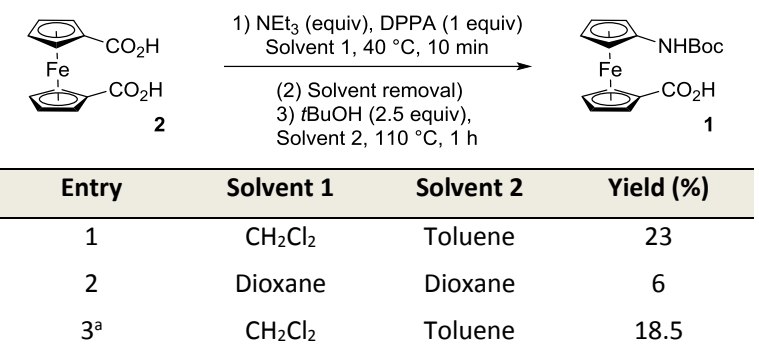
$a$ Reaction mixture filtrated over Amberjet $1000 \mathrm{H}$ resin before rearrangement.

Puzzled by these last results, we reasoned that the main difference in the two-step procedure was the intermediate purification of $\mathbf{3}$ and that, in the one-flask procedure, both $\mathbf{3}$ and $\mathbf{4}$ were present. Therefore, we subjected a mixture of pure 3 and 4 in a 1:1.9 ratio, as obtained in the first step, to the Curtius rearrangement (Scheme 2). The yield of 1 dropped from $70 \%$ (when pure 3 is used) to $20 \%$ in this last case, therefore indicating that the presence of mono- and bisacyl azide was detrimental to the outcome of the reaction.

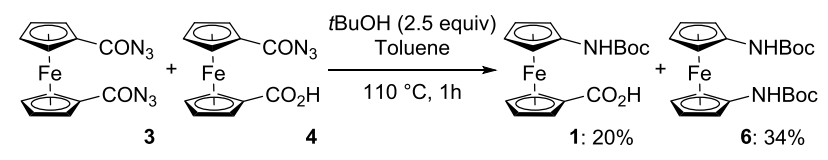

Scheme 2. Curtius rearrangement of a mixture of $\mathbf{3}$ and $\mathbf{4}$.

It is difficult to rationalize why the presence of multiple isocyanides favors decomposition. However, it has been proposed that, on prolonged heating, thermolysis of ferrocenyl isocyanate could lead to iron-stabilized nitrene, able to deliver the corresponding amine by proton abstraction from the solvent. ${ }^{92}$ The latter could then react with a remaining isocyanate to give various ureas. ${ }^{19,} 39$ Carboxylic acids are also known to react with isocyanates and generate mixed carbamic-carboxylic anhydrides. ${ }^{93-96}$ Such reactive groups could further generate symmetrical and unsymmetrical ureas. As we used disubstituted substrates, all these reactions could lead to polar polyureas and decomposition products. Indeed, after the Curtius rearrangement step, an insoluble black precipitate was invariably observed, as well as baseline spots by thinlayer chromatography.

As it proved difficult to perform a one-flask reaction, we went back to a two-step protocol and made four $N$-protected Fca by the reaction of 4 with various alcohols. The best yield was observed with tBuOH (1), whereas benzyl alcohol, 9-fluorenemethanol and allyl alcohol reacted equally to give the corresponding Fca derivatives (79, Scheme 3).

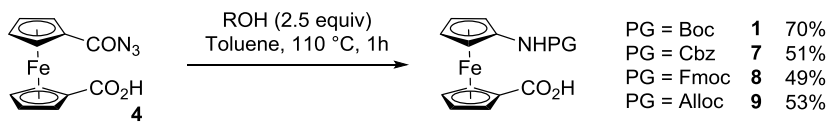

Scheme 3. Curtius rearrangement of $\mathbf{4}$ applied to the synthesis of protected Fca.

No analytical details are reported on the $\mathrm{Cbz}$ derivative 7 whereas the Alloc-protected Fca $\mathbf{9}$ is new. Consequently, we carried out the complete elucidation of their structure in both solution and solid- 
state. In solution, 2D NMR experiments were performed, and selected NOESY and HMBC correlations are depicted in Figure 4. For all the Fca derivatives, strong NOESY correlations were noticed between the $\mathrm{NH}$ and the adjacent ferrocenic protons. Additional correlations were also observed between the $\mathrm{NH}$ and the proton of the upper $\mathrm{Cp}$ ring, suggesting a certain degree of free rotation of the two $\mathrm{Cp}$ rings in DMSO-d 6 .
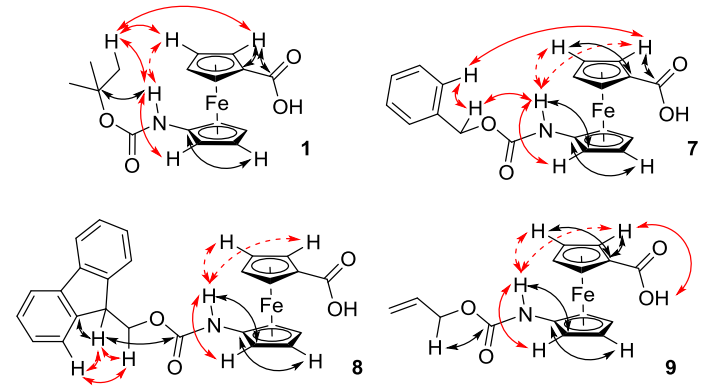

Figure 4. Selected NOESY (red arrows) and HMBC (black arrows) correlations observed by 2D NMR for 1, 7-9. Plain and dash arrows indicate strong and weak correlations, respectively.

At the solid state, the Alloc derivative $\mathbf{9}$ adopts a dimer structure, as reported for the Boc and Fmoc analogs (Figure 5). ${ }^{40,97}$ Indeed, two molecules of 9 are connected by two eight-membered rings: one between the two carboxylic acids with $\mathrm{O}^{7}-\mathrm{H}^{7} \cdots \mathrm{O}^{27}$ and $\mathrm{O}^{28}-\mathrm{H}^{28 \ldots \mathrm{O}^{8}}$ hydrogen bonds (1.8 (5) and 1.9 (6) $\AA$, respectively; the other made of hydrogen bonds between the $\mathrm{NH}$ carbamate and one oxygen of the other carbamoyl moiety $\left(2.0 \AA\right.$ for both $\mathrm{N}^{14}-\mathrm{H}^{14 \ldots} \mathrm{O}^{36}$ and $\mathrm{N}^{34}$ $\left.\mathrm{H}^{34 \ldots \mathrm{O}^{16}}\right)$. According to their lengths and corresponding angles, they are strong hydrogen bonds. ${ }^{98,}, 99$ For both molecules of the dimer, $C p$ rings of each ferrocenyl group are almost coplanar ( $C p-C p$ planes angle, molecule A: $2.0^{\circ}$; molecule B: $1.0^{\circ}$ ) but slightly eclipsed (pseudo rotation angle, molecule $\mathrm{A}: \mathrm{C}^{25}-\mathrm{Cg}^{3} \cdots \mathrm{Cg}^{4}-\mathrm{C}^{33}: 12.7^{\circ}$; molecule B: $\left.C^{5}-C g^{1 \cdots} C g^{2}-C^{13}: 14.2^{\circ}\right)$

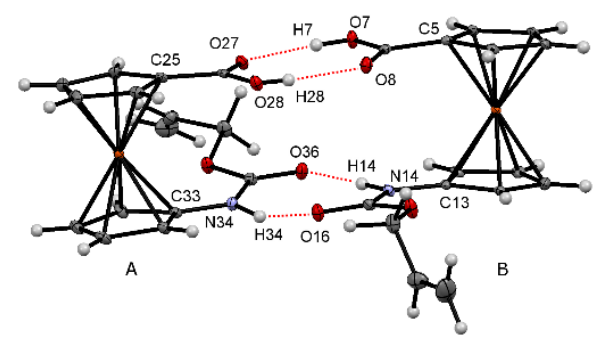

Figure 5. Molecular structure of compound 9 (thermal ellipsoids shown at the $30 \%$ probability level).

On the other hand, a molecule of water co-crystallized with the $\mathrm{Cbz}$ derivative 7, resulting in a completely different hydrogen bonding network (Figures 6 and 7). Due to that additional water molecule, dimers are no longer observed. Hydrogen bonds are present between the carboxyl acid and water $\left(\mathrm{O}^{8}-\mathrm{H}^{8} \ldots \mathrm{OW}^{1}, 1.74(2)\right.$ $\AA)$ and between water and the $\mathrm{CO}$ carbamate $\left(\mathrm{OW}^{1}-\mathrm{HW}^{1 \mathrm{~A} \ldots} \ldots \mathrm{O}^{7}\right.$ and $\mathrm{OW}^{1}-\mathrm{HW}^{1 \mathrm{~B}} \ldots \mathrm{O}^{18}, 1.89(2)$ and 1.86 (3) $\AA$, respectively), as depicted on Figure 7. A last $\mathrm{N}^{16}-\mathrm{H}^{16 \ldots} \mathrm{O}^{7}$ hydrogen bond $(2.16$ (2) $\AA$ ) helps to structure the crystal. The $\mathrm{Cp}$ rings appear almost coplanar (Cp-Cp planes angle $2.7^{\circ}$ ) and adopt an eclipsed conformation (pseudo torsion angle $\left.\mathrm{C}^{5}-\mathrm{Cg}^{1} \ldots \mathrm{Cg}^{2}-\mathrm{C}^{15}: 1.0^{\circ}\right)$

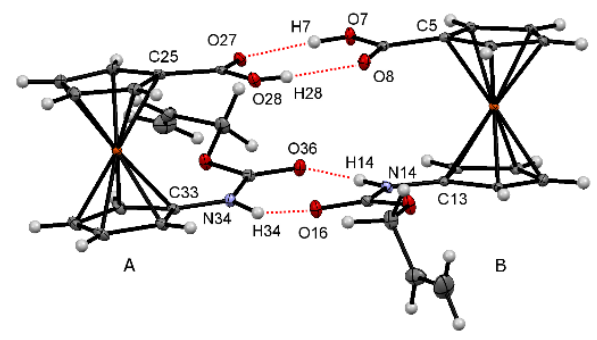

Figure 6. Molecular structure of compound $\mathbf{7}$ (thermal ellipsoids shown at the $30 \%$ probability level).

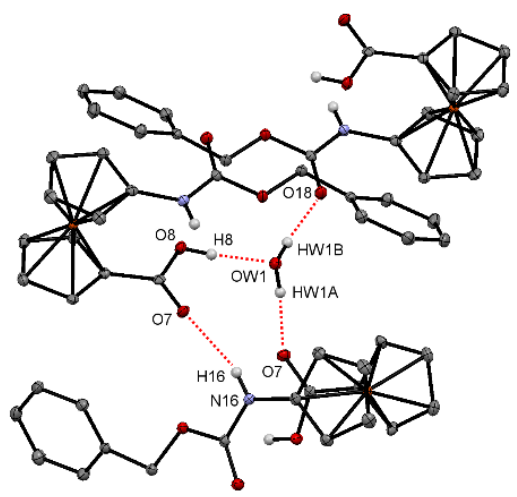

Figure 7. Hydrogen bonds observed at the solid state for $\mathbf{7}$ ( $\mathrm{H}$ atoms not involved in hydrogen bonds were omitted for clarity).

The reaction of $\mathrm{N}$-acetylated and $\mathrm{N}$-Boc Fca with 1hydroxybenzotriazole ( $\mathrm{HOBt}$ ) have been reported to deliver the activated esters in good yields. ${ }^{27,} 38,40$ In order to extend the chemistry of Fca derivatives, we here prepared the four activated esters $10-13$ by reacting the carboxylic acid with $N$ hydroxysuccinimide (NHS) in the presence of 1-ethyl-3-(3dimethylaminopropyl)carbodiimide (EDC) as coupling agent (Scheme 4). Good yields were obtained, apart for $\mathbf{1 0}$ for which the formation of the corresponding anhydride $\mathbf{1 4}$ was also noticed. ${ }^{24,100}$

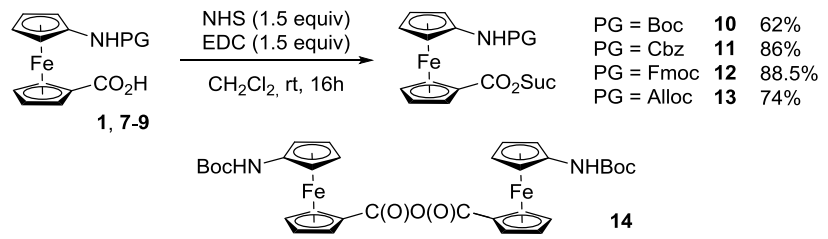

Scheme 4. Fca activated esters 10-13 syntheses and formula of anhydride 14.

In solution, NOESY NMR experiments helped elucidate the structure of the four activated esters (Figure 8). First, the absence of any correlation between succinimidyl's methylene protons and the carbamate protecting group tends to suggest that the two substituents are away from each other. Then, the moderate to strong correlations observed between the carbamate $\mathrm{NH}$ and ferrocenic protons on the upper $\mathrm{Cp}$ ring suggest that both substituents are opposite. The correlation between Boc group's methyl protons and the ferrocenic protons on the upper $\mathrm{Cp}$ ring support that hypothesis. 

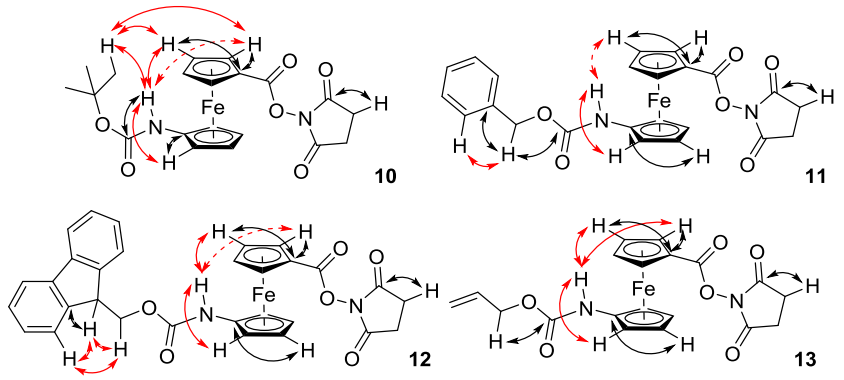

Figure 8. Selected NOESY (red arrows) and HMBC (black arrows) correlations observed by 2D NMR for 10-13. Plain and dash arrows indicate strong and weak correlations, respectively.

This was confirmed by the X-ray crystal structure of $\mathbf{1 0}$ (Figure 9). Indeed, contrary to the $\mathrm{N}$-acetylated and $\mathrm{N}$-Boc HOBt activated ester of Fca, both substituents are opposed. The $\mathrm{Cp}$ rings are almost

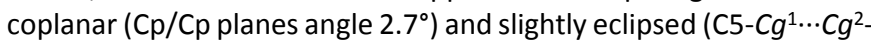
$\mathrm{C}^{23}$ pseudo torsion angle $7.6^{\circ}$ ). The succinidimyl ring is rotated out of the plane of the ester by $88.5^{\circ}$ (close to PhCOOSuc $\left.87.8^{\circ}\right)^{101}$ whereas a $80.8^{\circ}$ angle was noted for the HOBt activated ester. The C-O ester bond $(1.395 \AA)$ is shorter when compared to HOBt activated esters (1.423 $\AA$ for the $N$-acetylated and $1.429 \AA$ for the $N$-Boc derivatives, respectively). However, the succinidimyl derivatives share a similar level of reactivity toward methylamine with $93 \%$ yield for the synthesis of $\mathbf{1 5}$ under standard conditions (Scheme 5).

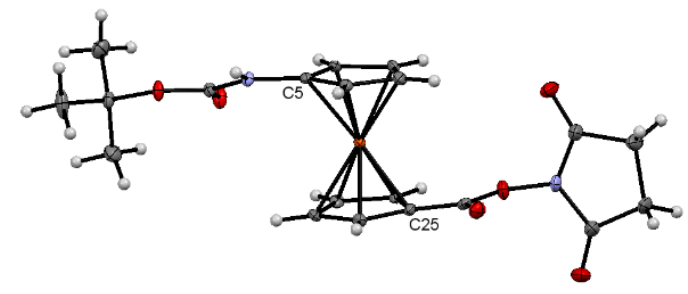

Figure 9. Molecular structure of compound $\mathbf{1 0}$ (thermal ellipsoids shown at the $30 \%$ probability level).

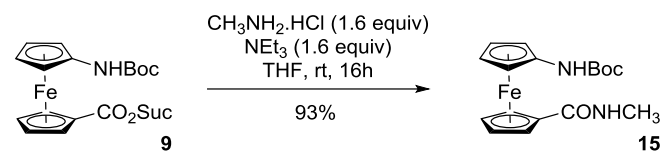

Scheme 5. Coupling of $\mathbf{9}$ with methylamine toward 15.

\section{Conclusions}

We studied the desymmetrizing Curtius rearrangement from ferrocene-1,1'-dicarboxylic acid toward $N$-protected $1^{\prime}$ aminoferrocene-1-carboxylic acid. A careful optimization of each step revealed the thermal instability of 1 '-isocyanatoferrocene-1carboxylic acid and the probable formation of polyferrocenic amides when two different acyl azides are mixed.

We therefore developed a two-step protocol, able to deliver various $\mathrm{N}$-protected Fca in good yields. They were further elaborated into succinimidyl activated esters, for coupling with amines. The structure of various products was elucidated both at the solid state and in solution. It makes little doubt that this shortest synthesis of 1 '-aminoferrocene-1-carboxylic acid derivatives will help chemists to access original structures for various applications. Our efforts towards such biologically active ferrocene derivatives and sensors will be reported in due course.

\section{Experimental}

General Details. Unless otherwise stated, all the reactions were performed under air. Column chromatography separations were achieved on silica gel (40-63 $\mu \mathrm{m})$. Melting points were measured on a Kofler apparatus. IR spectra were taken on a Perkin-Elmer Spectrum 100 spectrometer. ${ }^{1} \mathrm{H}$ and ${ }^{13} \mathrm{C}$ Nuclear Magnetic Resonance (NMR) spectra were recorded either (i) on a Bruker Avance III spectrometer at $300 \mathrm{MHz}$ and $75 \mathrm{MHz}$, respectively, or/and (ii) on a Bruker Avance III HD at $500 \mathrm{MHz}$ and $125.7 \mathrm{MHz}$, respectively. ${ }^{1} \mathrm{H}$ chemical shifts $(\delta)$ are given in ppm relative to the solvent residual peak and ${ }^{13} \mathrm{C}$ chemical shifts are relative to the central peak of the solvent signal. ${ }^{102}$

For 3, 4, 5, 7, 9 and 10, the X-ray diffraction data were collected using D8 VENTURE Bruker AXS or APEXII Bruker AXS diffractometers at the temperature given in the crystal data. The samples were studied with monochromatized Mo-K $\alpha$ radiation $(\lambda=0.71073 \AA$ ). The structure was solved by dual-space algorithm using the SHELXT program, ${ }^{103}$ and then refined with full-matrix least-square methods based on $F^{2}$ (SHELXL). ${ }^{104}$ All non-hydrogen atoms were refined with anisotropic atomic displacement parameters. $\mathrm{H}$ atoms were finally included in their calculated positions. The molecular diagrams were generated by MERCURY (version 3.5.1). Ferrocene-1,1'-dicarboxylic acid is commercially available but can also be prepared from ferrocene following the procedure described in SI.

Triethylammonium 1'-carboxyferrocene-1-carboxylate (5) and bis triethylammonium 1,1'-ferrrocene carboxylate mixture. Triethylamine (167 mg, $1.2 \mathrm{mmol}, 4.0$ equiv) was added to a solution of ferrocene-1,1'-dicarboxylic acid $(2,82.2 \mathrm{mg}, 0.3 \mathrm{mmol}$, 1.0 equiv) in $\mathrm{DCM}(5.0 \mathrm{~mL})$. After $5 \mathrm{~min}$ stirring at room temperature, volatiles were removed under vacuum to give the crude product as an orange solid (quant.). It is composed of a 1:0.3 mixture of mono- and bis-ammonium. $\mathrm{mp} 240-242^{\circ} \mathrm{C}$ (decomp.); IR (ATR): 2474 (br), 1682, 1588, 1461, 1380, 1320, 1244, 1154, 1022, $820,787,725 \mathrm{~cm}^{-1}$; ${ }^{1} \mathrm{H}$ NMR ( $300 \mathrm{MHz}, \mathrm{CDCl}_{3}$ ) (major ammonium described) $\delta 4.66(\mathrm{t}, J=1.8 \mathrm{~Hz}, 4 \mathrm{H}, 4 \times \mathrm{FcCH}), 4.34(\mathrm{t}, J=1.8 \mathrm{~Hz}, 4 \mathrm{H}$, $4 \times \mathrm{FcCH}$ ), 3.01 (q, J = 7.2 Hz, 8H, $\left.4 \times \mathrm{CH}_{2}\right), 1.25$ (t, J = 7.2 Hz, $12 \mathrm{H}, 4$ $\left.\times \mathrm{CH}_{3}\right) ;{ }^{13} \mathrm{C}$ NMR (75.4 MHz, $\mathrm{CDCl}_{3}$ ) (major ammonium described) $\delta$ $175.6(2 \times \mathrm{C}=\mathrm{O}), 77.2$ ( $2 \times \mathrm{FCC}$, seen by $\mathrm{HMBC}$ correlations), 72.2 (4 $x \mathrm{FcCH}), 71.8(4 \times \mathrm{FcCH}), 45.1\left(4 \times \mathrm{CH}_{2}\right), 9.2\left(4 \times \mathrm{CH}_{3}\right)$. Crystal data for 5. $\mathrm{C}_{12} \mathrm{H}_{9} \mathrm{FeO}_{4}, \mathrm{C}_{6} \mathrm{H}_{16} \mathrm{~N} ; M=375.24, T=150(2) \mathrm{K}$, orthorhombic $P b c a, a=14.193(7), b=11.681(4), c=21.035(10) \AA, V=3487(3)$ $\AA^{3} . Z=8, d=1.429 \mathrm{~g} . \mathrm{cm}^{-3}, \mu=0.886 \mathrm{~mm}^{-1}$. A final refinement on $F^{2}$ with 3990 unique intensities and 221 parameters converged at $\mathrm{W} R\left(F^{2}\right)=0.1203(R(F)=0.0493)$ for 3372 observed reflections with I $>2 \sigma(I)$. CCDC 1584020 .

1'-Azidocarbonylferrocene-1-carboxylic acid (4). DPPA (280 $\mu \mathrm{L}$, $358 \mathrm{mg}, 1.3 \mathrm{mmol}, 1.0$ equiv) was added to a solution of ferrocene1,1'-dicarboxylic acid (2, $356 \mathrm{mg}, 1.3 \mathrm{mmol}, 1.0$ equiv) and trimethylamine ( $725 \mu \mathrm{L}, 526 \mathrm{mg}, 5.2 \mathrm{mmol}, 4.0$ equiv) in DCM ( 2.5 $\mathrm{mL})$. After 10 min stirring at room temperature, $\mathrm{HCl}(1 \mathrm{M}, 30 \mathrm{~mL})$ was added and the reaction mixture was extracted with DCM $(3 \mathrm{x}$ $20 \mathrm{~mL}$ ). The combined organic layers were dried over $\mathrm{MgSO}_{4}$, filtrated and concentrated under vacuum to give the crude product. This was purified by column chromatography on silica, eluting with EtOAc/heptane (50:50 to 40:60) with few drops of TFA to give 1,1'diazidocarbonylferrocene 3 (92.1 $\mathrm{mg}, 22 \%)$ and 1'- 
azidocarbonylferrocene-1-carboxylic acid 4 (250 mg, 64\%) as deep red solids. 1,1'-diazidocarbonylferrocene (3): $\mathrm{mp}$ 118-120 ${ }^{\circ} \mathrm{C}$ (decomp., lit. ${ }^{105} 112-115{ }^{\circ} \mathrm{C}$ ); IR (ATR): 3110, 2140, 1676, 1449, $1371,1258,1183,1056,986,894,819,746 \mathrm{~cm}^{-1} ;{ }^{1} \mathrm{H}$ NMR $(300 \mathrm{MHz}$, $\left.\mathrm{CDCl}_{3}\right) \delta 4.90(\mathrm{t} J=2.0 \mathrm{~Hz}, 4 \mathrm{H}, 4 \times \mathrm{FcCH}), 4.56(\mathrm{t}, J=2.0 \mathrm{~Hz}, 4 \mathrm{H}, 4 \mathrm{x}$ $\mathrm{FcCH}) ;{ }^{13} \mathrm{C} \mathrm{NMR}\left(75.4 \mathrm{MHz}, \mathrm{CDCl}_{3}\right) \delta 175.7(2 \times \mathrm{C}=\mathrm{O}), 74.6$ ( $\left.2 \times \mathrm{FcC}\right)$, $74.3(4 \times \mathrm{FcCH}), 72.3(4 \times \mathrm{FcCH})$. Anal. Calcd for $\mathrm{C}_{12} \mathrm{H}_{8} \mathrm{FeN}_{6} \mathrm{O}_{2}: \mathrm{C}$, 44.47; H, 2.49; N, 25.93. Found: C, 44.39; H, 2.60; N, 26.02. Crystal data for 3. $\mathrm{C}_{12} \mathrm{H}_{8} \mathrm{FeN}_{6} \mathrm{O}_{2}, M=324.09, T=150 \mathrm{~K}$, orthorhombic $P b c a, a=5.8627(6), b=16.8493(16), c=25.022(2) \AA, V=2471.8(4)$

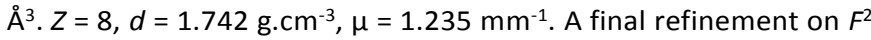
with 2806 unique intensities and 190 parameters converged at $\mathrm{W} R\left(F^{2}\right)=0.0925(R(F)=0.0448)$ for 2369 observed reflections with $/$ $>2 \sigma(I)$. CCDC 1584017. 1'-Azidocarbonylferrocene-1-carboxylic acid (4): $\mathrm{mp} 150-152^{\circ} \mathrm{C}$; IR (ATR): 2886 (br), 2147, 1684, 1659, 1481, 1450, 1406, 1287, 1260, 1199, 1168, 1056, 987, 895, 819, $742 \mathrm{~cm}^{-1}$; ${ }^{1} \mathrm{H}$ NMR $\left(300 \mathrm{MHz}, \mathrm{CDCl}_{3}\right) \delta 4.91(\mathrm{~s}, 2 \mathrm{H}, 2 \times \mathrm{FCCH}), 4.88(\mathrm{~s}, 2 \mathrm{H}, 2 \mathrm{x}$ $\mathrm{FcCH}), 4.56(\mathrm{~s}, 2 \mathrm{H}, 2 \times \mathrm{FcCH}), 4.49(\mathrm{~s}, 2 \mathrm{H}, 2 \times \mathrm{FcCH}) ;{ }^{1} \mathrm{H}$ NMR (500 $\left.\mathrm{MHz}, \mathrm{DMSO}-\mathrm{d}^{6}\right) \delta 12.43\left(\mathrm{br} \mathrm{s}, 1 \mathrm{H}, \mathrm{CO}_{2} \mathrm{H}\right), 4.81(\mathrm{t}, J=1.7 \mathrm{~Hz}, 2 \mathrm{H}, 2 \mathrm{x}$ $\mathrm{FcCH}), 4.77(\mathrm{t}, J=1.7 \mathrm{~Hz}, 2 \mathrm{H}, 2 \times \mathrm{FcCH}), 4.65(\mathrm{t}, J=1.7 \mathrm{~Hz}, 2 \mathrm{H}, 2 \mathrm{x}$ $\mathrm{FcCH}), 4.56(\mathrm{t}, J=1.7 \mathrm{~Hz}, 2 \mathrm{H}, 2 \times \mathrm{FcCH}) ;{ }^{13} \mathrm{C}$ NMR $(126 \mathrm{MHz}$, DMSO$\left.d^{6}\right) \delta 174.9\left(\mathrm{CON}_{3}\right), 170.4\left(\mathrm{CO}_{2} \mathrm{H}\right), 74.4(\mathrm{FcC}), 74.1(2 \times \mathrm{FcCH}), 73.3$ ( $\mathrm{FcC}), 72.8(2 \times \mathrm{FcCH}), 71.9(2 \times \mathrm{FcCH}), 71.3(2 \mathrm{H}, 2 \times \mathrm{FcCH})$. Anal. Calcd for $\mathrm{C}_{12} \mathrm{H}_{9} \mathrm{FeN}_{3} \mathrm{O}_{3}: \mathrm{C}, 48.19 ; \mathrm{H}, 3.03 ; \mathrm{N}, 14.05$. Found: $\mathrm{C}, 48.28$; $\mathrm{H}, 3.11 ; \mathrm{N}, 14.16$. Crystal data for 4. $\mathrm{C}_{12} \mathrm{H}_{9} \mathrm{FeN}_{3} \mathrm{O}_{3}, M=299.07, T=$ $295 \mathrm{~K}$, triclinic $P-1, a=5.8750(2), b=7.3536(3), c=14.1683(5) \AA$, $\alpha$ $=76.132(2), \beta=79.3330(10), \gamma=79.2490(10)^{\circ}, V=577.47(4) \AA^{3} . Z$ $=2, d=1.720 \mathrm{~g} . \mathrm{cm}^{-3}, \mu=1.313 \mathrm{~mm}^{-1}$. A final refinement on $F^{2}$ with 2552 unique intensities and 169 parameters converged at $\mathrm{w} R\left(F^{2}\right)=$ $0.0744(R(F)=0.0324)$ for 2148 observed reflections with $I>2 \sigma(I)$. CCDC 1584016.

General procedure 1. The appropriate alcohol (2.5 equiv) was added to a stirred solution of $1^{\prime}$-azidocarbonylferrocene-1carboxylic acid (4, 1.0 equiv) in toluene $(0.16 \mathrm{M})$ and the reaction mixture was heated for 50-60 $\mathrm{min}$ at toluene reflux temperature. The reaction mixture was cooled to room temperature and purified by column chromatography on silica, eluting with EtOAc/heptane (50:50 to $90: 10)$ to give the title product.

1'-((tert-Butoxycarbonyl)amino)ferrocene-1-carboxylic acid (1). The general procedure 1 using 1'-azidocarbonylferrocene-1carboxylic acid $(4,119 \mathrm{mg}, 0.4 \mathrm{mmol})$ and $t \mathrm{BuOH}(94.0 \mu \mathrm{L}, 74.1 \mathrm{mg}$, $1.0 \mathrm{mmol}$ ) afforded the title product as an orange solid $(96.5 \mathrm{mg}$, 70\%). mp 145-150 ${ }^{\circ} \mathrm{C}$ (lit. ${ }^{39} 145.5-146{ }^{\circ} \mathrm{C}$ ); IR (ATR): 2974 (br), 1698 $1668,1488,1394,1362,1287,1160,1069,1020,945,807,777 \mathrm{~cm}$ ${ }^{1}$; ${ }^{1} \mathrm{H}$ NMR (500 MHz, DMSO-d $) \delta 11.97$ (br s, $1 \mathrm{H}, \mathrm{CO}_{2} \mathrm{H}$ ), 8.54 (br s, $1 \mathrm{H}, \mathrm{NH}), 4.60(\mathrm{~s}, 2 \mathrm{H}, 2 \times \mathrm{FcCH}), 4.49(\mathrm{br} \mathrm{s}, 2 \mathrm{H}, 2 \times \mathrm{FcCH}), 4.32(\mathrm{~s}, 2 \mathrm{H}$, $2 \times \mathrm{FcCH}), 3.92(\mathrm{~s}, 2 \mathrm{H}, 2 \times \mathrm{FcCH}), 1.45\left(\mathrm{~s}, 9 \mathrm{H}, \mathrm{C}\left(\mathrm{CH}_{3}\right)_{3}\right) ;{ }^{13} \mathrm{C} \mathrm{NMR}(125.7$ $\left.\mathrm{MHz}, \mathrm{DMSO}-\mathrm{d}^{6}\right) \delta 171.9\left(\mathrm{C}=\mathrm{O}_{\text {acid }}\right), 152.9\left(\mathrm{C}=\mathrm{O}_{\text {carbamate }}\right), 98.8$ (FcC),

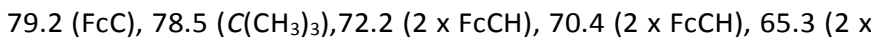

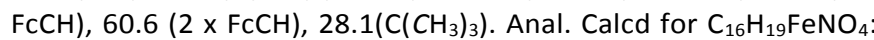
C, 55.67; H, 5.55; N, 4.06. Found: C, 55.78; H, 5.67; N, 4.15.

1'-((Benzyloxycarbonyl)amino)ferrocene-1-carboxylic acid (7). The general procedure 1 using $1^{\prime}$-azidocarbonylferrocene-1-carboxylic acid $(4,239 \mathrm{mg}, 0.8 \mathrm{mmol})$ and benzyl alcohol ( $207 \mu \mathrm{L}, 216 \mathrm{mg}, 2.0$ $\mathrm{mmol}$ ) afforded the title product as an orange solid (154 $\mathrm{mg}, 51 \%$ ).

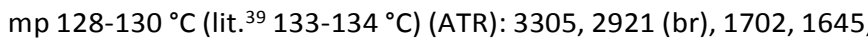
$1566,1478,1396,1287,1257,1209,1170,1091,1026,930,738 \mathrm{~cm}$ ${ }^{1}$; ${ }^{1} \mathrm{H}$ NMR $\left(500 \mathrm{MHz}, \mathrm{DMSO}-\mathrm{d}^{6}\right) \delta 12.02\left(\mathrm{br} \mathrm{s}, 1 \mathrm{H}, \mathrm{CO}_{2} \mathrm{H}\right), 9.01(\mathrm{~s}, 1 \mathrm{H}$, $\mathrm{NH})$, 7.40-7.36 (m, $4 \mathrm{H}, 4 \times \mathrm{ArCH}), 7.34-7.33(\mathrm{~m}, 1 \mathrm{H}, \mathrm{ArCH}), 5.11(\mathrm{~s}$ $\left.2 \mathrm{H}, \mathrm{CH}_{2}\right), 4.62(\mathrm{~s}, 2 \mathrm{H}, 2 \mathrm{x} \mathrm{FCCH}), 4.52(\mathrm{~s}, 2 \mathrm{H}, 2 \mathrm{xFCCH}), 4.32(\mathrm{~s}, 2 \mathrm{H}, 2 \mathrm{x}$
$\mathrm{FcCH}), 3.95$ (s, 2H, 2x FcCH); $\left.{ }^{13} \mathrm{C} \mathrm{NMR} \mathrm{(125.7} \mathrm{MHz,} \mathrm{CDCl}_{3}, 298 \mathrm{~K}\right) \delta$ $171.8\left(\mathrm{C}=\mathrm{O}_{\text {acid }}\right), 153.5\left(\mathrm{C}=\mathrm{O}_{\text {carbamate }}\right), 138.4(\mathrm{ArC}), 128.4(2 \times \mathrm{ArCH})$, 127.9 ( $\mathrm{ArCH}), 127.8(2 \times \mathrm{ArCH}), 98.3(\mathrm{FcC}), 72.4(\mathrm{FcC}), 72.2(2 \times \mathrm{FcCH})$, $70.6(2 \times \mathrm{FcCH}), 65.6\left(\mathrm{CH}_{2}\right), 65.5(2 \times \mathrm{FcCH}), 60.7(2 \times \mathrm{FcCH})$. Anal. Calcd for $\mathrm{C}_{19} \mathrm{H}_{17} \mathrm{FeNO}_{4}$ : C, 60.18; $\mathrm{H}, 4.52 ; \mathrm{N}, 3.69$. Found: $\mathrm{C}, 60.26$; $\mathrm{H}, 4.61 ; \mathrm{N}, 3.80$. Crystal data for 7. $\mathrm{C}_{19} \mathrm{H}_{17} \mathrm{FeNO}_{4}, \mathrm{H}_{2} \mathrm{O}, \mathrm{M}=397.20$, $T=150 \mathrm{~K}$, monoclinic $P 2_{1} / c, a=14.4756(6), b=7.4476(3), c=$ 17.2948(8) $\AA, \beta=114.161(2)^{\circ}, V=1701.19(13) \AA^{3} . Z=4, d=1.551$ g.cm ${ }^{-3}, \mu=0.918 \mathrm{~mm}^{-1}$. A final refinement on $F^{2}$ with 3871 unique intensities and 247 parameters converged at $\mathrm{w} R\left(F^{2}\right)=0.0680(R(F)$ $=0.0289)$ for 3261 observed reflections with $I>2 \sigma(l)$. CCDC 1584018

\section{1'-[((Fluoren-9-yl)methoxycarbonyl)amino]ferrocene-1-}

carboxylic acid (8). The general procedure 1 using $1^{\prime}$ azidocarbonylferrocene-1-carboxylic acid $(4,239 \mathrm{mg}, 0.8 \mathrm{mmol})$ and $(9 \mathrm{H}$-fluoren-9-yl)methanol (SI4, $392 \mathrm{mg}, 2.0 \mathrm{mmol}$ ) afforded the title product as a yellow solid (185 mg, 49\%). mp 128-130 ${ }^{\circ} \mathrm{C}$ (decomp.); IR (ATR): 2957 (br), 1699, 1662, 1479, 1324, 1289, 1080, $736 \mathrm{~cm}^{-1} ;{ }^{1} \mathrm{H}$ NMR $\left(500 \mathrm{MHz}\right.$, DMSO-d $\left.{ }^{6}\right) \delta 11.99\left(\mathrm{~s}, 1 \mathrm{H}, \mathrm{CO}_{2} \mathrm{H}\right), 9.00$ (s, $1 \mathrm{H}, \mathrm{NH}), 7.91(\mathrm{~d}, J=7.0 \mathrm{~Hz}, 2 \mathrm{H}, 2 \times \mathrm{AcCH}), 7.74(\mathrm{~d}, J=7.0 \mathrm{~Hz}, 2 \mathrm{H}$, $2 \times \mathrm{ArCH}), 7.43(\mathrm{t}, J=7.0 \mathrm{~Hz}, 2 \mathrm{H}, 2 \times \mathrm{ArCH}), 7.36(\mathrm{t}, J=7.0 \mathrm{~Hz}, 2 \mathrm{H}, 2$ $\times \mathrm{ArCH}), 4.60(\mathrm{~s}, 2 \mathrm{H}, 2 \times \mathrm{FcCH}), 4.53(\mathrm{~s}, 2 \mathrm{H}, 2 \times \mathrm{FcCH}), 4.44(\mathrm{~s}, 2 \mathrm{H}$, $\left.\mathrm{CH}_{2}\right), 4.28(\mathrm{~s}, 2 \mathrm{H}, 2 \times \mathrm{FcCH}), 3.94(\mathrm{~s}, 2 \mathrm{H}, 2 \times \mathrm{FcCH}) ;{ }^{13} \mathrm{C} \mathrm{NMR}(125.7$ $\left.\mathrm{MHz}, \mathrm{DMSO}-\mathrm{d}^{6}\right) \delta 171.9\left(\mathrm{C}=\mathrm{O}_{\text {acid }}\right), 153.4\left(\mathrm{C}=\mathrm{O}_{\text {carbamate }}\right), 143.8(2 \mathrm{x}$ $\operatorname{ArC}), 140.8(2 \times \mathrm{ArC}), 140.8(2 \times \mathrm{ArC}), 127.6(2 \times \mathrm{ArCH}), 127.1(2 \times$ $\mathrm{ArCH}), 125.1$ ( $2 \times \mathrm{ArCH}), 120.1$ ( $2 \times \mathrm{ArCH}), 98.3(\mathrm{FcC}), 72.3(2 \times \mathrm{FcCH})$, $70.5(2 \times \mathrm{FCH}), 65.5(2 \times \mathrm{FcCH}), 65.3\left(\mathrm{CH}_{2}\right), 60.6(2 \times \mathrm{FcCH}), 46.7(\mathrm{CH})$. One FcC missing. Anal. Calcd for $\mathrm{C}_{26} \mathrm{H}_{21} \mathrm{FeNO}_{4}: \mathrm{C}, 66.83 ; \mathrm{H}, 4.53 ; \mathrm{N}$, 3.00. Found: C, 66.92; H, 4.66; N, 3.11 .

1'-((Allyloxycarbonyl)amino)ferrocene-1-carboxylic acid (9). The general procedure 1 using 1 '-azidocarbonylferrocene-1-carboxylic acid $(4,239 \mathrm{mg}, 0.8 \mathrm{mmol})$ and allyl alcohol (136 $\mu \mathrm{L}, 116 \mathrm{mg}, 2.0$ $\mathrm{mmol}$ ) afforded the title product as a yellow solid (139 $\mathrm{mg}, 53 \%$ ).

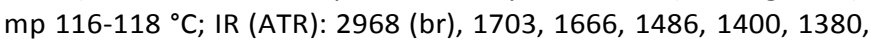
$1323,1295,1167,1071,1026,994,812,765,749 \mathrm{~cm}^{-1}$; ${ }^{1} \mathrm{H}$ NMR (500 $\left.\mathrm{MHz}, \mathrm{DMSO}-\mathrm{d}^{6}\right) \delta 12.00\left(\mathrm{~s}, 1 \mathrm{H}, \mathrm{CO}_{2} \mathrm{H}\right), 8.95(\mathrm{~s}, 1 \mathrm{H}, \mathrm{NH}), 5.96(\mathrm{~m}, 1 \mathrm{H}$, $H C=C H H), 5.33(\mathrm{~d}, \mathrm{~J}=17.3 \mathrm{~Hz}, 1 \mathrm{H}, \mathrm{HC}=\mathrm{CHH}), 5.22(\mathrm{~d}, \mathrm{~J}=10.4 \mathrm{~Hz}, 1 \mathrm{H}$, $\mathrm{HC}=\mathrm{CHH}), 4.62(\mathrm{~s}, 2 \mathrm{H}, 2 \times \mathrm{FcCH}), 4.55\left(\mathrm{~d}, \mathrm{~J}=4.1 \mathrm{~Hz}, 2 \mathrm{H}, \mathrm{CH}_{2}\right), 4.51(\mathrm{~s}$, $2 \mathrm{H}, 2 \times \mathrm{FcCH}), 4.34(\mathrm{~s}, 2 \mathrm{H}, 2 \times \mathrm{FcCH}), 3.94(\mathrm{~s}, 2 \mathrm{H}, 2 \times \mathrm{FcCH}) ;{ }^{13} \mathrm{C} \mathrm{NMR}$ $\left(125.7 \mathrm{MHz}, \mathrm{DMSO}-\mathrm{d}^{6}\right) \delta 171.8\left(\mathrm{C}=\mathrm{O}_{\text {acid }}\right), 153.3\left(\mathrm{C}=\mathrm{O}_{\text {carbamate }}\right), 133.4$ $(\mathrm{HC}=\mathrm{CHH}), 117.2(\mathrm{HC}=\mathrm{CHH}), 98.3(\mathrm{FcC}), 72.4(\mathrm{FcC}), 72.2(2 \times \mathrm{FcCH})$, $70.5(2 \times \mathrm{FcCH}), 65.4$ ( $2 \times \mathrm{FcCH}), 64.5\left(\mathrm{CH}_{2}\right), 60.7$ ( $\left.2 \times \mathrm{FcCH}\right)$. Anal. Calcd for $\mathrm{C}_{15} \mathrm{H}_{15} \mathrm{FeNO}_{4}$ : $\mathrm{C}, 54.74 ; \mathrm{H}, 4.59 ; \mathrm{N}, 4.26$. Found: $\mathrm{C}, 54.85$; $\mathrm{H}, 4.72 ; \mathrm{N}, 4.35$. Crystal data for 9. $\mathrm{C}_{15} \mathrm{H}_{15} \mathrm{FeNO}_{4}, \mathrm{M}=329.13, T=$ $150(2) \mathrm{K}$, triclinic $P-1, a=8.4320(9), b=11.1582(11), c=$ 15.5903(15) $\AA, \alpha=69.828(3), \beta=85.294(4), \gamma=85.800(4)^{\circ}, V=$ $1370.6(2) \AA^{3} . Z=4, d=1.595 \mathrm{~g} \cdot \mathrm{cm}^{-3}, \mu=1.115 \mathrm{~mm}^{-1}$. A final refinement on $F^{2}$ with 6273 unique intensities and 385 parameters converged at $\mathrm{w} R\left(F^{2}\right)=0.1152(R(F)=0.0452)$ for 5362 observed reflections with $I>2 \sigma(I)$. CCDC 1584021.

General procedure 2. Under argon, $N$-hydroxysuccinimide (1.5 equiv) and $E D C . H C l$ (1.5 equiv) were added to a solution of the corresponding protected $1^{\prime}$-aminoferrocene-1-carboxylic acid (1.0 equiv) in anhydrous DCM $(0.1 \mathrm{M})$. After $5 \mathrm{~h}$ stirring at room temperature, volatiles were removed under vacuum to give the crude product. This was purified by column chromatography on silica, eluting with EtOAc/heptane (50:50) to give the title product as an orange solid.

2,5-Dioxopyrrolidin-1-yl 1'-(tert-butylcarbonylamino)ferrocene-1carboxylate (10). The general procedure 2 using $1^{\prime}$-(tert- 
butylcarbonylamino)ferrocene-1-carboxylic acid (1, $345 \mathrm{mg}, 1.0$ mmol, 1.0 equiv), $N$-hydroxysuccinimide (172 mg, $1.5 \mathrm{mmol}, 1.5$ equiv) and $\mathrm{EDC} . \mathrm{HCl}(287 \mathrm{mg}, 1.5 \mathrm{mmol}, 1.5$ equiv) afforded the title product as an orange solid $(276 \mathrm{mg}, 62 \%)$ and $1^{\prime}-(($ tert butoxycarbonyl)amino)ferrocene-1-carboxylic anhydride $(14,23$ $\mathrm{mg}, 7 \%)$ as a red solid. 1'-((tert-Butoxycarbonyl)amino)ferrocene1-carboxylic anhydride (14): $\mathrm{mp} 165-167^{\circ} \mathrm{C}$ (lit. ${ }^{24} 167-168{ }^{\circ} \mathrm{C}$ ); IR (ATR): 3316, 2979, 1762, 1706, 1688, 1552, 1389, 1368, 1356, 1239, $1161,1065,1041,1002,905,878,825,755 \mathrm{~cm}^{-1} ;{ }^{1} \mathrm{H} \mathrm{NMR}(500 \mathrm{MHz}$, $\left.\mathrm{CDCl}_{3}\right) \delta 6.36(\mathrm{~s}, 2 \mathrm{H}, 2 \times \mathrm{NH}), 4.82(\mathrm{~s}, 4 \mathrm{H}, 4 \times \mathrm{FcCH}), 4.68(\mathrm{~s}, 4 \mathrm{H}, 4 \times$ $\mathrm{FcCH}), 4.56(\mathrm{~s}, 4 \mathrm{H}, 4 \times \mathrm{FcCH}), 4.08(\mathrm{~s}, 4 \mathrm{H}, 4 \times \mathrm{fcCH}), 1.43(\mathrm{~s}, 18 \mathrm{H}, 2 \mathrm{x}$ $\mathrm{C}\left(\mathrm{CH}_{3}\right)_{3} ;{ }^{13} \mathrm{C}$ NMR $\left(125.7 \mathrm{MHz}, \mathrm{CDCl}_{3}\right) \delta 168.6\left(2 \times \mathrm{C}=\mathrm{O}_{\text {anhydride }}\right), 153.5$ ( $\left.\mathrm{C}=\mathrm{O}_{\text {carbamate }}\right), 99.0(2 \times \mathrm{FcC}), 80.4\left(2 \times \mathrm{C}\left(\mathrm{CH}_{3}\right)_{3}\right), 74.2(4 \times \mathrm{FcCH}), 72.2$ ( $4 \times \mathrm{fcCH}), 70.1(2 \times \mathrm{FcCH}), 66.3(4 \times \mathrm{FcCH}), 62.4(4 \times \mathrm{FcCH}), 28.5(2 \times$ $\left.\mathrm{C}\left(\mathrm{CH}_{3}\right)_{3}\right)$. 2,5-Dioxopyrrolidin-1-yl 1'-(tert-butoxycarbonyl amino)ferrocene-1-carboxylate (10): $\mathrm{mp}$ 112-116 ${ }^{\circ} \mathrm{C}$; IR (ATR): $3357,1761,1723,1539,1444,1367,264,1242,1206,1158,1070$, $981,879,822,746 \mathrm{~cm}^{-1}$; ${ }^{1} \mathrm{H}$ NMR (500 MHz, DMSO-d $\left.{ }^{6}\right) \delta 8.56$ (br s, $1 \mathrm{H}, \mathrm{NH}), 4.87(\mathrm{~s}, 2 \mathrm{H}, 2 \times \mathrm{FcCH}), 4.60(\mathrm{br} \mathrm{s}, 2 \mathrm{H}, 2 \times \mathrm{FcCH}), 4.57(\mathrm{~s}, 2 \mathrm{H}$ $2 \times \mathrm{FcCH}), 4.19(\mathrm{~s}, 2 \mathrm{H}, 2 \times \mathrm{FcCH}), 2.86\left(\mathrm{~s}, 4 \mathrm{H}, 2 \times \mathrm{CH}_{2}\right), 1.45(\mathrm{~s}, 9 \mathrm{H}$, $\left.\mathrm{C}\left(\mathrm{CH}_{3}\right)_{3}\right) ;{ }^{13} \mathrm{C}$ NMR $\left(125.7 \mathrm{MHz}, \mathrm{DMSO}-\mathrm{d}^{6}\right) \delta 170.6$ ( $\left.\mathrm{C}=\mathrm{O}_{\text {succinimidy }}\right)$, $166.9\left(\mathrm{C}=\mathrm{O}_{\text {ester }}\right), 152.8\left(\mathrm{C}=\mathrm{O}_{\text {carbamate }}\right), 99.8(\mathrm{FcC}), 78.8\left(\mathrm{C}\left(\mathrm{CH}_{3}\right)_{3}\right), 74.9$ $(2 \times \mathrm{FcCH}), 70.6(2 \times \mathrm{FcCH}), 66.9(2 \times \mathrm{FcCH}), 63.5(\mathrm{FcC}), 61.4(2 \times$

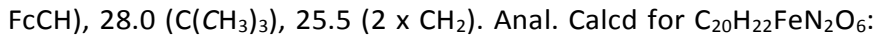
C, 54.32; H, 5.01; N, 6.33. Found: C, 54.40; H, 5.11; N, 6.45. Crystal data for 10. $\mathrm{C}_{20} \mathrm{H}_{22} \mathrm{FeN}_{2} \mathrm{O}_{6}, M=442.24, T=150(2) \mathrm{K}$, monoclinic $P 2_{1} / c, a=21.3600(13), b=10.0652(5), c=9.5245(6) \AA, \beta=$ 96.112(2) ${ }^{\circ}, V=2036.1(2) \AA^{3} . Z=4, d=1.443 \mathrm{~g} . \mathrm{cm}^{-3}, \mu=0.780 \mathrm{~mm}$ 1. A final refinement on $F^{2}$ with 4645 unique intensities and 265 parameters converged at $\mathrm{w} R\left(F^{2}\right)=0.1664(R(F)=0.0620)$ for 3849 observed reflections with $I>2 \sigma(I)$. CCDC 1584019.

2,5-Dioxopyrrolidin-1-yl 1'-((benzyloxycarbonyl)amino)ferrocene1-carboxylate (11). The general procedure 2 using $1^{\prime}$ ((benzyloxycarbonyl)amino)ferrocene-1-carboxylic acid $(7,45.5 \mathrm{mg}$ $0.12 \mathrm{mmol}, 1.0$ equiv), $N$-hydroxysuccinimide $(34.5 \mathrm{mg}, 0.18 \mathrm{mmol}$, 1.5 equiv) and $\mathrm{EDC} . \mathrm{HCl}(20.7 \mathrm{mg}, 0.18 \mathrm{mmol}, 1.5$ equiv) afforded the title product as an orange solid $(49.0 \mathrm{mg}, 86 \%)$. mp $70-74{ }^{\circ} \mathrm{C}$; IR (ATR): 3316, 1760, 1722, 1550, 1446, 1373, 1264, 1232, 1200, 1069, $1028,986,884,816,744,697 \mathrm{~cm}^{-1} ;{ }^{1} \mathrm{H}$ NMR $\left(500 \mathrm{MHz}\right.$, DMSO-d $\left.{ }^{6}\right) \delta$ $9.02(\mathrm{~s}, 1 \mathrm{H}, \mathrm{NH}), 7.40(\mathrm{~s}, 4 \mathrm{H}, 4 \times \operatorname{ArCH}), 7.34(\mathrm{~s}, 1 \mathrm{H}, \mathrm{ArCH}), 5.12(\mathrm{~s}$, $\left.2 \mathrm{H}, \mathrm{CH}_{2}\right), 4.87(\mathrm{~s}, 2 \mathrm{H}, 2 \times \mathrm{FcCH}), 4.63(\mathrm{~s}, 2 \mathrm{H}, 2 \times \mathrm{FcCH}), 4.56(\mathrm{~s}, 2 \mathrm{H}, 2$ $x \mathrm{FcCH}), 4.22(\mathrm{~s}, 2 \mathrm{H}, 2 \times \mathrm{FcCH}), 2.84\left(\mathrm{~s}, 4 \mathrm{H}, 2 \times \mathrm{CH}_{2}\right) ;{ }^{13} \mathrm{C} \mathrm{NMR}(125.7$ $\left.\mathrm{MHz}, \mathrm{DMSO}-\mathrm{d}^{6}\right) \delta 170.6 \quad\left(\mathrm{C}=\mathrm{O}_{\text {succinimidyl }}\right), 166.9$ ( $\left.\mathrm{C}=\mathrm{O}_{\text {ester }}\right), 153.5$ $\left(\mathrm{C}=\mathrm{O}_{\text {carbamate }}\right), 136.7(\mathrm{ArC}), 128.4(2 \times \mathrm{ArCH}), 128.0(\mathrm{ArCH}), 127.9(2 \mathrm{x}$ $\mathrm{ArCH}), 99.2$ ( $\mathrm{FCC}) ; 75.0(2 \times \mathrm{FcCH}), 70.8(2 \times \mathrm{FcCH}), 67.0(2 \times \mathrm{FcCH})$, $65.8\left(\mathrm{CH}_{2}\right), 63.7(\mathrm{FcC}), 61.5(2 \times \mathrm{FcCH}), 25.5\left(2 \times \mathrm{CH}_{2}\right)$. Anal. Calcd for $\mathrm{C}_{23} \mathrm{H}_{20} \mathrm{FeN}_{2} \mathrm{O}_{6}: \mathrm{C}, 58.00 ; \mathrm{H}, 4.23 ; \mathrm{N}, 5.88$. Found: $\mathrm{C}, 58.09 ; \mathrm{H}, 4.29 ; \mathrm{N}$, 5.99 .

\section{2,5-Dioxopyrrolidin-1-yl}

1'-[(fluoren-9yl)methoxycarbonyl)amino]ferrocene-1-carboxylate (12). The general procedure 2 using $1^{\prime}-[(($ fluoren-9yl)methoxycarbonyl)amino]ferrocene-1-carboxylic acid $(\mathbf{8}, 56.1 \mathrm{mg}$, $0.12 \mathrm{mmol}, 1.0$ equiv), $\mathrm{N}$-hydroxysuccinimide $(34.5 \mathrm{mg}, 0.18 \mathrm{mmol}$ 1.5 equiv) and $\mathrm{EDC} . \mathrm{HCl}(20.7 \mathrm{mg}, 0.18 \mathrm{mmol}, 1.5$ equiv) afforded the title product as an orange solid (59.9 mg, 88.5\%). mp 80-84 ${ }^{\circ} \mathrm{C}$; IR (ATR): 3253, 1760, 1724, 1551, 1447, 1373, 1233, 1203, 1071, 986 , $884,741 \mathrm{~cm}^{-1} ;{ }^{1} \mathrm{H}$ NMR $\left(500 \mathrm{MHz}, \mathrm{DMSO}-\mathrm{d}^{6}\right) \delta 8.98$ (br s, $\left.1 \mathrm{H}, \mathrm{NH}\right)$, $7.91(\mathrm{~d}, J=6.9 \mathrm{~Hz}, 2 \mathrm{H}, 2 \times \mathrm{ArCH}), 7.73(\mathrm{~d}, J=6.9 \mathrm{~Hz}, 2 \mathrm{H}, 2 \times \mathrm{ArCH})$, $7.43(\mathrm{t}, J=6.9 \mathrm{~Hz}, 2 \mathrm{H}, 2 \times \mathrm{ArCH}), 7.36(\mathrm{t}, J=6.9 \mathrm{~Hz}, 2 \mathrm{H}, 2 \times \mathrm{ArCH})$ $4.85(\mathrm{~s}, 2 \mathrm{H}, 2 \times \mathrm{FcCH}), 4.63(\mathrm{~s}, 2 \mathrm{H}, 2 \times \mathrm{FcCH}), 4.50$ (s, 4H, $2 \times \mathrm{FcCH}$,
$\left.\mathrm{CH}_{2}\right), 4.29(\mathrm{~s}, 1 \mathrm{H}, \mathrm{CH}), 4.21(\mathrm{~s}, 2 \mathrm{H}, 2 \times \mathrm{FcCH}), 2.85\left(\mathrm{~s}, 4 \mathrm{H}, 2 \times \mathrm{CH}_{2}\right) ;{ }^{13} \mathrm{C}$ NMR (125.7 MHz, DMSO-d $\left.{ }^{6}\right) \delta 170.6\left(\mathrm{C}=\mathrm{O}_{\text {succinimidyl }}\right), 166.8$ ( $\left.\mathrm{C}=\mathrm{O}_{\text {ester }}\right)$, $153.3\left(\mathrm{C}=\mathrm{O}_{\text {carbamate }}\right), 143.7(2 \times \mathrm{ArC}), 140.8(2 \times \mathrm{ArCH}), 127.6(2 \times$ $\mathrm{ArCH}), 127.0(2 \times \mathrm{ArCH}), 125.0(2 \times \mathrm{ArCH}), 120.1(2 \times \mathrm{ArCH}), 99.2$ ( $\mathrm{FCC}), 74.9(2 \times \mathrm{FcCH}), 70.7(2 \times \mathrm{FcCH}), 69.9(2 \times \mathrm{FcCH}), 65.2\left(\mathrm{CH}_{2}\right)$, 63.6 (FcC), $61.4(2 \times \mathrm{FcCH}), 46.7(\mathrm{CH}), 25.4\left(2 \times \mathrm{CH}_{2}\right)$. Anal. Calcd for $\mathrm{C}_{30} \mathrm{H}_{24} \mathrm{FeN}_{2} \mathrm{O}_{6}: \mathrm{C}, 63.85 ; \mathrm{H}, 4.29 ; \mathrm{N}, 4.96$. Found: $\mathrm{C}, 63.97 ; \mathrm{H}, 4.40 ; \mathrm{N}$, 5.07 .

2,5-Dioxopyrrolidin-1-yl 1'-((allyloxycarbonyl)amino)ferrocene -1carboxylate (13). The general procedure 2 using $1^{\prime}$ ((allyloxycarbonyl)amino)ferrocene-1-carboxylic acid (9, $49.4 \mathrm{mg}$, $0.12 \mathrm{mmol}, 1.0$ equiv), $\mathrm{N}$-hydroxysuccinimide $(34.5 \mathrm{mg}, 0.18 \mathrm{mmol}$, 1.5 equiv) and $\mathrm{EDC} . \mathrm{HCl}(20.7 \mathrm{mg}, 0.18 \mathrm{mmol}, 1.5$ equiv) afforded the title product as an orange solid $(47.7 \mathrm{mg}, 74 \%) . \mathrm{mp} 80-84{ }^{\circ} \mathrm{C}$; IR (ATR): 3331, 1760, 1722, 1548, 1446, 1372, 1264, 1233, 1201, 1070, 988, 933, 885, 816, $747 \mathrm{~cm}^{-1} ;{ }^{1} \mathrm{H}$ NMR (500 MHz, DMSO-d $\left.{ }^{6}\right) \delta 8.97$ (s, $1 \mathrm{H}, \mathrm{NH}), 5.95(\mathrm{~m}, 1 \mathrm{H}, \mathrm{HC}=\mathrm{CHH}), 5.33(\mathrm{~d}, J=17.3 \mathrm{~Hz}, 1 \mathrm{H}, \mathrm{HC}=\mathrm{CHH})$, $5.23(\mathrm{~d}, J=10.3 \mathrm{~Hz}, 1 \mathrm{H}, \mathrm{HC}=\mathrm{CHH}), 4.89(\mathrm{~s}, 2 \mathrm{H}, 2 \times \mathrm{FcCH}), 4.63(\mathrm{~s}, 2 \mathrm{H}$, $2 \times \mathrm{FcCH}), 4.59(\mathrm{~s}, 2 \mathrm{H}, 2 \times \mathrm{FcCH}), 4.57\left(\mathrm{~s}, 2 \mathrm{H}, \mathrm{CH}_{2}\right), 4.22(\mathrm{~s}, 2 \mathrm{H}, 2 \times$ $\mathrm{FcCH}), 2.86\left(\mathrm{~s}, 4 \mathrm{H}, 2 \times \mathrm{CH}_{2}\right) ;{ }^{13} \mathrm{C}$ NMR $\left(125.7 \mathrm{MHz}, \mathrm{DMSO}-\mathrm{d}^{6}\right) \delta 170.6$ $\left(\mathrm{C}=\mathrm{O}_{\text {succinimidyl }}\right), 166.9\left(\mathrm{C}=\mathrm{O}_{\text {ester }}\right), 153.3\left(\mathrm{C}=\mathrm{O}_{\text {carbamate }}\right), 133.3\left(\mathrm{HC}=\mathrm{CH}_{2}\right)$, $117.3\left(\mathrm{HC}=\mathrm{CH}_{2}\right), 99.3(\mathrm{FcC}), 75.0(2 \times \mathrm{FcCH}), 70.8(2 \times \mathrm{FcCH}), 67.0(2$ $x \mathrm{FcCH}), 64.7\left(\mathrm{CH}_{2}\right), 63.7(\mathrm{FcC}), 61.5(2 \times \mathrm{FcCH}), 25.5\left(2 \times \mathrm{CH}_{2}\right)$. Anal. Calcd for $\mathrm{C}_{19} \mathrm{H}_{18} \mathrm{FeN}_{2} \mathrm{O}_{6}$ : $\mathrm{C}, 53.54 ; \mathrm{H}, 4.26 ; \mathrm{N}, 6.57$. Found: $\mathrm{C}, 53.63$; $\mathrm{H}, 4.38 ; \mathrm{N}, 6.68$.

$\mathrm{N}$-methyl $\quad \mathbf{1}^{\prime}$-((tert-butoxycarbonyl)amino)ferrocene-1carboxamide (15). Under argon, triethylamine $(44.6 \mu \mathrm{L}, 32.3 \mathrm{mg}$, $0.3 \mathrm{mmol}, 1.6$ equiv) was added to a solution of 2,5-dioxopyrrolidin1-yl 1'-(tert-butylcarbonylamino)ferrocene-1-carboxylate (10, 88.5 $\mathrm{mg}, 0.2 \mathrm{mmol}, 1.0$ equiv) and methylamine hydrochloride $(26.1 \mathrm{mg}$, $0.3 \mathrm{mmol}, 1.6$ equiv) in anhydrous THF $(0.8 \mathrm{~mL})$ and the reaction mixture was stirred at $\mathrm{rt}$ overnight. Direct purification by column chromatography on silica, eluting with heptane/EtOAc (50:50 to 30:70) afforded the title product as an orange solid (66.9 $\mathrm{mg}, 93 \%)$. $\mathrm{mp} 70-80^{\circ} \mathrm{C}$; IR (ATR): 3290 (br), 2975 (br), 1694, 1627, 1547, 1388, $1365,1245,1158,1068,1019,939,879,813,755 \mathrm{~cm}^{-1} ;{ }^{1} \mathrm{H}$ NMR (500 $\left.\mathrm{MHz}, \mathrm{DMSO}-\mathrm{d}^{6}\right) \delta 8.39\left(\mathrm{~s}, 1 \mathrm{H}, \mathrm{NH}_{\text {amide }}\right), 7.61\left(\mathrm{~s}, 1 \mathrm{H}, \mathrm{NH}_{\text {carbamate }}\right), 4.66$ $(\mathrm{s}, 2 \mathrm{H}, 2 \times \mathrm{FcCH}), 4.43(\mathrm{~s}, 2 \mathrm{H}, 2 \times \mathrm{FcCH}), 4.21(\mathrm{~s}, 2 \mathrm{H}, 2 \times \mathrm{FcCH}), 3.87$ (s, $2 \mathrm{H}, 2 \times \mathrm{FcCH}), 2.69\left(\mathrm{~s}, 3 \mathrm{H}, \mathrm{CH}_{3}\right), 1.44\left(\mathrm{~s}, 9 \mathrm{H}, \mathrm{C}\left(\mathrm{CH}_{3}\right)_{3}\right) ;{ }^{13} \mathrm{C} \mathrm{NMR}$ (125.7 MHz, DMSO-d $\left.{ }^{6}\right) \delta 169.1\left(\mathrm{C}=\mathrm{O}_{\text {amide }}\right), 153.0$ ( $\left.\mathrm{C}=\mathrm{O}_{\text {carbamate }}\right), 98.0$ ( $\mathrm{FCC}), 78.5\left(\mathrm{C}\left(\mathrm{CH}_{3}\right)_{3}\right), 77.5(\mathrm{FcC}), 70.7(2 \times \mathrm{FcCH}), 68.6(2 \times \mathrm{FcCH}), 65.1$

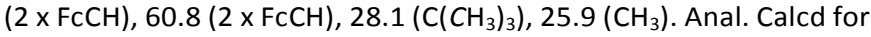
$\mathrm{C}_{17} \mathrm{H}_{22} \mathrm{FeN}_{2} \mathrm{O}_{3}: \mathrm{C}, 57.00 ; \mathrm{H}, 6.19 ; \mathrm{N}, 7.82$. Found: $\mathrm{C}, 57.09 ; \mathrm{H}, 6.30 ; \mathrm{N}$, 7.94.

\section{Conflicts of interest}

There are no conflicts to declare.

\section{Acknowledgements}

This work was supported by the Université de Rennes 1 . We acknowledge FEDER founds (D8 VENTURE Bruker AXS diffractometer). W. E. would like to thank J. Mongin for technical assistance and Prof. F. Mongin for critically reviewing this document and for making valuable suggestions. 


\section{References}

1.

R. S. Herrick, R. M. Jarret, T. P. Curran, D. R. Dragoli, M. B. Flaherty, S. E. Lindyberg, R. A. Slate and L. C. Thornton, Tetrahedron Lett., 1996, 37, 5289-5292.

2. A. Lataifeh, S. Beheshti and H.-B. Kraatz, Eur. J. Inorg. Chem., 2009, 2009, 3205-3218.

3. T. Moriuchi and T. Hirao, Acc. Chem. Res., 2010, 43, 10401051.

4. B. Albada and N. Metzler-Nolte, Chem. Rev., 2016, 116, 11797-11839.

5. L. Barisic, M. Dropucic, V. Rapic, H. Pritzkow, S. I. Kirin and N. Metzler-Nolte, Chem. Commun., 2004, 2004-2005.

$6 . \quad$ L. Barišić, V. Rapić and N. Metzler-Nolte, Eur. J. Inorg. Chem., 2006, 12, 4019-4021.

7. L. Barišić, M. Čakić, K. A. Mahmoud, Y.-n. Liu, H.-B. Kraatz, H. Pritzkow, S. I. Kirin, N. Metzler-Nolte and V. Rapić, Chem. Eur. J., 2006, 12, 4965-4980.

8. M. Č. Semenčić, D. Siebler, K. Heinze and V. Rapić, Organometallics, 2009, 28, 2028-2037.

9. V. Kovač, K. Radolović, I. Habuš, D. Siebler, K. Heinze and V. Rapić, Eur. J. Inorg. Chem., 2009, 2009, 389-399.

10. M. Č. Semenčić, K. Heinze, C. Förster and V. Rapić, Eur. J. Inorg. Chem., 2010, 2010, 1089-1097.

11. L. Barišić, M. Roščić, M. Kovačević, M. Č. Semenčić, Š. Horvat and V. Rapić, Carbohydr. Res., 2011, 346, 678-684. L. Barišić, M. Kovačević, M. Mamić, I. Kodrin, Z. Mihalić and V. Rapić, Eur. J. Inorg. Chem., 2012, 2012, 1810-1822. C. Förster, M. Kovačević, L. Barišić, V. Rapić and K. Heinze, Organometallics, 2012, 31, 3683-3694.

14. M. Kovačević, K. Molčanov, K. Radošević, V. Srček, S. Roca, A. Čače and L. Barišić, Molecules, 2014, 19, 12852.

15. M. A. K. Khan, Y.-T. Long, G. Schatte and H.-B. Kraatz, Anal. Chem., 2007, 79, 2877-2884.

16. K. A. Mahmoud and H.-B. Kraatz, Chem. Eur. J., 2007, 13 5885-5895.

17. M. A. K. Khan, Heinz-Bernhard 2009 Patent CA2605026 (A1), Univ. Saskatchewan.

18. D. Siebler, C. Förster and K. Heinze, Eur. J. Inorg. Chem., 2010, 2010, 523-527.

19. K. Mahmoud, Y.-T. Long, G. Schatte and H.-B. Kraatz, J. Organomet. Chem., 2004, 689, 2250-2255.

20. S. Chowdhury, G. Schatte and H.-B. Kraatz, Angew. Chem. Int. Ed., 2006, 45, 6882-6884.

21. K. Heinze and D. Siebler, Z. Anorg. Allg. Chem., 2007, 633, 2223-2233.

22. K. Heinze, U. Wild and M. Beckmann, Eur. J. Inorg. Chem., 2007, 2007, 617-623.

23. K. A. Mahmoud and H.-B. Kraatz, J. Inorg. Organomet. P., 2008, 18, 69-80.

24. D. Siebler, C. Förster and K. Heinze, Eur. J. Inorg. Chem., 2010, 2010, 3986-3992.

25. D. Siebler, C. Forster and K. Heinze, Dalton Trans., 2011, 40, 3558-3575.

$26 . \quad$ D. Siebler, M. Linseis, T. Gasi, L. M. Carrella, R. F. Winter, C. Förster and K. Heinze, Chem. Eur. J., 2011, 17, 45404551.

27. Khaled A. Mahmoud, Y.-T. Long, G. Schatte and H.-B. Kraatz, Eur. J. Inorg. Chem., 2005, 2005, 173-180.
28. M. A. K. Khan, D. S. Thomas and H.-B. Kraatz, Inorg. Chim Acta, 2006, 359, 3339-3344.

29. M. Žabić, Z. Kukrić and L. Topalić-Trivunović, Chem. Ind. \& Chem. Eng. Q, 2009, 15, 251-256.

30. R. Ribić, Kovačević, M., Petrović-Peroković, V., GruićSovulj, I., Rapić, V., Tomić, S., Croat. Chem. Acta, 2010, 83, 421-431.

31. M. Labib, S. Martić, P. O. Shipman and H.-B. Kraatz, Talanta, 2011, 85, 770-778.

32. M. Labib, P. O. Shipman, S. Martić and H.-B. Kraatz, Electrochim. Acta, 2011, 56, 5122-5128.

33. P. Marzenell, H. Hagen, L. Sellner, T. Zenz, R. Grinyte, V. Pavlov, S. Daum and A. Mokhir, J. Med. Chem., 2013, 56, 6935-6944.

34. V. Kovač, K. Radošević, A. Bebek, J. Makarević, Z. Štefanić, L. Barišić, M. Žinić and V. Rapić, Appl. Organomet. Chem., 2016, 31, 1.

35. A. Neidlinger, C. Förster and K. Heinze, Eur. J. Org. Chem., 2016, 2016, 4852-4864.

36. J. Melomedov, J. R. Ochsmann, M. Meister, F. Laquai and K. Heinze, Eur. J. Inorg. Chem., 2014, 2014, 2902-2915.

37. I. R. Butler and S. C. Quayle, J. Organomet. Chem., 1998, 552, 63-68.

38. T.-a. Okamura, K. Sakauye, N. Ueyama and A. Nakamura, Inorg. Chem., 1998, 37, 6731-6736.

39. L. Barišić, V. Rapić and V. Kovač, Croat. Chem. Acta, 2002, 75, 199-210.

40. K. Heinze and M. Schlenker, Eur. J. Inorg. Chem., 2004, 2004, 2974-2988.

41. T. N. Wheeler and J. Ray, J. Org. Chem., 1987, 52, 4875 4877.

42. W. Q. Ong, H. Zhao, X. Fang, S. Woen, F. Zhou, W. Yap, H. Su, S. F. Y. Li and H. Zeng, Org. Lett., 2011, 13, 3194-3197.

43. J. Liang, J. E. Cochran, W. A. Dorsch, I. Davies and M. P. Clark, Org. Process Res. Dev., 2016, 20, 965-969.

44. D. P. Walker, S. E. Heasley, A. Maclnnes, T. Anjeh, H.-F. Lu, Y. M. Fobian, J. T. Collins, M. L. Vazquez and M. K. Mao, Synlett, 2011, 2011, 2959-2962.

45. A. Berkessel, K. Glaubitz and J. Lex, Eur. J. Org. Chem., 2002, 2002, 2948-2952.

46. M. a. J. Figueira, O. Caamaño, F. Fernández, X. GarcíaMera and M. D. García, Tetrahedron, 2002, 58, 967-974.

47. A. Ogawa, F. Ujjainwalla, L. Chu, B. Li, L. Wei, J. Xu, H. Ok, A. Lackner and I. Kopka 2015 Patent US 9.029.377 B2, Merck Sharp \& Dohme Corp.

48. J. Aubé, C. Fehl, R. Liu, M. C. McLeod and H. F. Motiwala, in Comprehensive Organic Synthesis: Second Edition, eds. P. Knochel and G. A. Molander, Elsevier, 2014, vol. 6, pp. 598-635.

49. T. Shioiri, in Comprehensive Organic Synthesis, eds. B. M. Trost and I. Fleming, Pergamon Press: Oxford, 1991, vol. 6, pp. 795-828.

50. U. Heiser, A. J. Niestroj and L. Zeitlmann 2011 Patent WO 2011/110612 A1, Ingenium Pharmaceuticals GMBH.

51. J. D. White and S. Shaw, Org. Lett., 2011, 13, 2488-2491.

52. S. Sharma, S. Gupta, V. Khajuria, A. Bhagat, Z. Ahmed and B. A. Shah, Bioorg. Med. Chem. Lett., 2016, 26, 695-698.

53. D. Zhang, H. Zheng and X. Wang, Tetrahedron, 2016, 72, 1941-1953. 

4762.

55. R. Haraguchi and S. Matsubara, Org. Lett., 2013, 15, 33783380.

56. V. Pace, L. Castoldi and W. Holzer, Chem. Commun., 2013, 49, 8383-8385.

57. W. Yang, X. Sun, W. Yu, R. Rai, J. R. Deschamps, L. A. Mitchell, C. Jiang, A. D. MacKerell and F. Xue, Org. Lett., 2015, 17, 3070-3073.

58. K. Nemoto, S. Tanaka, M. Konno, S. Onozawa, M. Chiba, Y Tanaka, Y. Sasaki, R. Okubo and T. Hattori, Tetrahedron, 2016, 72, 734-745.

59. H. P. Hemantha, G. Chennakrishnareddy, T. M. Vishwanatha and V. V. Sureshbabu, Synlett, 2009, 2009, 407-410.

60. A. S. Singh, D. Kumar, N. Mishra and V. K. Tiwari, RSC Advances, 2016, 6, 84512-84522.

61. A. R. Kulkarni, S. Garai and G. A. Thakur, J. Org. Chem., 2017, 82, 992-999.

62.

63.

H. Lebel and O. Leogane, Org. Lett., 2005, 7, 4107-4110.

M. Baumann, I. R. Baxendale, S. V. Ley, N. Nikbin, C. D. Smith and J. P. Tierney, Org. Biomol. Chem, 2008, 6, 1577 1586.

64. J. K. Augustine, A. Bombrun, A. B. Mandal, P. Alagarsamy, R. N. Atta and P. Selvam, Synthesis, 2011, 2011, 14771483.

65. H. Hopf, S. V. Narayanan and P. G. Jones, Beilstein J. Org. Chem., 2015, 11, 437-445.

66. B. Movassagh and Y. Zakinezhad, Chem. Lett., 2005, 34, 1330-1331.

67. H. S. Lalithamba, T. M. Vishwanatha, M. S. Reddy and V. V. Sureshbabu, Synlett, 2012, 23, 1516-1522.

68. H. Teng, Z. Zhang, Y. Zhou, Z. Chen, Q. Chen, Y. Liu and W. $\mathrm{Xu}, \mathrm{RSC}$ Advances, 2015, 5, 71868-71872.

69. F. Zou, P. Yue, X. Zheng, D. Tang, W. Fu and Z. Li, J. Mater. Chem. A, 2016, 4, 10801-10805.

70. J. Cervelló and T. Sastre, Synthesis, 1990, 1990, 221-222.

71. D. V. Jawale, U. R. Pratap, N. Rahuja, A. K. Srivastava and R. A. Mane, Bioorg. Med. Chem. Lett., 2012, 22, 436-439. J. Broichhagen, J. A. Frank, N. R. Johnston, R. K. Mitchell, K. Smid, P. Marchetti, M. Bugliani, G. A. Rutter, D. Trauner and D. J. Hodson, Chem. Commun., 2015, 51, 6018-6021. D. B. Kastrinsky, J. Sangodkar, N. Zaware, S. Izadmehr, N. S. Dhawan, G. Narla and M. Ohlmeyer, Biorg. Med. Chem., 2015, 23, 6528-6534.

74. K. Hayashi, T. Choshi, K. Chikaraishi, A. Oda, R. Yoshinaga, N. Hatae, M. Ishikura and S. Hibino, Tetrahedron, 2012, 68, 4274-4279.

75. X. Cheng and S. P. Waters, Org. Lett., 2013, 15, 42264229.

76. T. J. Martin and T. Rovis, Angew. Chem. Int. Ed., 2013, 52, 5368-5371.

77. J. R. McCarthy, Tetrahedron Lett., 2015, 56, 6846-6847.

78. R. Shintani, R. Takano and K. Nozaki, Chem. Sci., 2016, 7, 1205-1211.

79.

80.
81. K. Ninomiya, T. Shioiri and S. Yamada, Tetrahedron, 1974, 30, 2151-2157.

82. S. B. Kahl and R. A. Kasar, J. Am. Chem. Soc., 1996, 118, 1223-1224.

83. A. Cho, T. W. Glinka, M. Ludwikow, A. T. Fan, M. Wang and S. J. Hecker, Bioorg. Med. Chem. Lett., 2001, 11, 137 140.

84. K. Nakayama, Y. Ishida, M. Ohtsuka, H. Kawato, K.-i. Yoshida, Y. Yokomizo, S. Hosono, T. Ohta, K. Hoshino, H. Ishida, K. Yoshida, T. E. Renau, R. Léger, J. Z. Zhang, V. J. Lee and W. J. Watkins, Bioorg. Med. Chem. Lett., 2003, 13, 4201-4204.

85. D. Braga, M. Polito, D. D'Addario and F. Grepioni, Cryst. Growth Des., 2004, 4, 1109-1112.

86. M.-S. Cheung, H.-S. Chan and Z. Xie, Dalton Trans., 2005, 2375-2381.

87. V. N. Kalinin, E. G. Rys, A. A. Tyutyunov, Z. A. Starikova, A A. Korlyukov, V. A. Ol'shevskaya, D. D. Sung, A. B. Ponomaryov, P. V. Petrovskii and E. Hey-Hawkins, Dalton Trans., 2005, 903-908.

88. M. R. Rizal and S. W. Ng, Acta Crystallogr. E, 2008, 64, 0992.

89. M. S. Newman and H. L. Gildenhorn, J. Am. Chem. Soc., 1948, 70, 317-319.

90. R. A. Coleman, M. S. Newman and A. B. Garrett, J. Am. Chem. Soc., 1954, 76, 4534-4538.

91. E. Fahr and L. Neumann, Angew. Chem., 1965, 77, 591591.

92. J. Lapić, G. Pavlović, D. Siebler, K. Heinze and V. Rapić, Organometallics, 2008, 27, 726-735.

93. W. Dieckmann and F. Breest, Ber. Deutsch. Chem. Ges. 1906, 39, 3052-3055.

94. W. R. Sorenson, J. Org. Chem., 1959, 24, 978-980.

95. C. Gürtler and K. Danielmeier, Tetrahedron Lett., 2004, 45, 2515-2521.

96. K. Sasaki and D. Crich, Org. Lett., 2011, 13, 2256-2259.

97. G. Pavlovic, L. Barisic, V. Rapic and V. Kovac, Acta Crystallogr. C, 2003, 59, m55-m57.

98. T. Steiner, Angew. Chem. Int. Ed., 2002, 41, 48-76.

99. G. R. Desiraju, Angew. Chem. Int. Ed., 2011, 50, 52-59.

100. M. Tazi, T. Roisnel, F. Mongin and W. Erb, Acta Crystallogr. C, 2017, 73.

101. Q. Meng, W. Zhang, Z. Sun, H. Zhang and M. Yu, Dyes Pigm., 2007, 75, 166-169.

102. H. E. Gottlieb, V. Kotlyar and A. Nudelman, J. Org. Chem., 1997, 62, 7512-7515.

103. G. Sheldrick, Acta Crystallogr. Sect. A, 2015, 71, 3-8.

104. G. Sheldrick, Acta Crystallogr. C, 2015, 71, 3-8.

105. J. Lapić, S. Djaković, M. Cetina, K. Heinze and V. Rapić, Eur. J. Inorg. Chem., 2010, 2010, 106-114. 